\title{
Article \\ Tph2 Gene Expression Defines Ethanol Drinking Behavior in Mice
}

\author{
Magdalena Zaniewska ${ }^{1,2, *(\mathbb{D} \text {, Valentina Mosienko }}{ }^{1,+}$, Michael Bader ${ }^{1,3,4,5}$ and Natalia Alenina ${ }^{1,5, *(D)}$ \\ 1 Max-Delbrück-Center for Molecular Medicine, Robert-Rössle-Str. 10, 13125 Berlin, Germany; \\ valentina.mosienko@bristol.ac.uk (V.M.); mbader@mdc-berlin.de (M.B.) \\ 2 Laboratory of Pharmacology and Brain Biostructure, Department of Pharmacology, Maj Institute of \\ Pharmacology, Polish Academy of Sciences, 12 Smętna Street, 31-343 Kraków, Poland \\ 3 Institute for Biology, University of Lübeck, Ratzeburger Allee 160, 23562 Lübeck, Germany \\ 4 Charité University Medicine Berlin, Charitéplatz 1, 10117 Berlin, Germany \\ 5 German Center for Cardiovascular Research (DZHK), Partner Site Berlin, Potsdamer Str. 58, \\ 10785 Berlin, Germany \\ * Correspondence: zaniew@if-pan.krakow.pl (M.Z.); alenina@mdc-berlin.de (N.A.); \\ Tel.: +48-1-2662-3289 (M.Z.); +49-30-9406-3576 (N.A.) \\ + Current address: School of Physiology, Pharmacology and Neuroscience, University of Bristol, \\ University Walk, Bristol BS8 1TD, UK.
}

Citation: Zaniewska, M.; Mosienko, V.; Bader, M.; Alenina, N. Tph2 Gene Expression Defines Ethanol Drinking Behavior in Mice. Cells 2022, 11, 874. https://doi.org/10.3390/ cells11050874

Academic Editor: Cord Brakebusch

Received: 18 January 2022

Accepted: 28 February 2022

Published: 3 March 2022

Publisher's Note: MDPI stays neutral with regard to jurisdictional claims in published maps and institutional affiliations.

Copyright: (c) 2022 by the authors. Licensee MDPI, Basel, Switzerland. This article is an open access article distributed under the terms and conditions of the Creative Commons Attribution (CC BY) license (https:// creativecommons.org/licenses/by/ $4.0 /)$.

\begin{abstract}
Indirect evidence supports a link between disrupted serotonin (5-hydroxytryptamine; $5-\mathrm{HT}$ ) signaling in the brain and addictive behaviors. However, the effects of hyposerotonergia on ethanol drinking behavior are contradictory. In this study, mice deficient in tryptophan hydroxylase $2\left(\mathrm{Tph}^{-{ }^{-}}\right)$, the rate-limiting enzyme of 5-HT synthesis in the brain, were used to assess the role of central 5-HT in alcohol drinking behavior. Life-long 5-HT depletion in these mice led to an increased ethanol consumption in comparison to wild-type animals in a two-bottle choice test. Water consumption was increased in naïve 5-HT-depleted mice. However, exposure of Tph $2^{-/}$animals to ethanol resulted in the normalization of water intake to the level of wild-type mice. Tph 2 deficiency in mice did not interfere with ethanol-evoked antidepressant response in the forced swim test. Gene expression analysis in wild-type animals revealed no change in Tph2 expression in the brain of mice consuming ethanol compared to control mice drinking water. However, within the alcohol-drinking group, inter-individual differences in chronic ethanol intake correlated with Tph2 transcript levels. Taken together, central 5-HT is an important modulator of drinking behavior in mice but is not required for the antidepressant effects of ethanol.
\end{abstract}

Keywords: central 5-HT; ethanol; mice; raphe nuclei; Tph2 knockout; Tph2 transcript

\section{Introduction}

Alcoholism is a chronic relapsing brain disorder defined by a loss of control over drinking despite known health consequences. Current first-line pharmacotherapies include naltrexone, the opioid receptor antagonist, and acamprosate, a drug that modulates glutamate and GABA-ergic signaling [1]. Disulfiram, which is an inhibitor of the acetaldehyde dehydrogenase, an enzyme responsible for ethanol metabolism, is a second-line treatment option [1]. The efficacy of these therapies is low, potentially due to the high diversity in treatment response between alcoholic individuals (for review [2]).

Epidemiological studies demonstrate the correlation between depression and alcohol dependence in humans [3]; however, their casual-connective relations have not been fully established yet [4,5]. Depressive symptoms commonly occur in the period preceding the development of alcohol dependence and very often initiate drug-taking behavior for selfmedication, a behavior called autotherapy. Conversely, in many individuals living with alcohol dependence, withdrawal from alcohol induces severe symptoms of depression, which, in turn, significantly increase the risk of relapse. The comorbidity of depression and 
alcohol abuse further hampers the researchers' ability to explain the molecular mechanisms underlying these brain disorders and to find effective pharmacotherapy.

Dysregulation of serotonin (5-hydroxytryptamine; 5-HT) neurotransmission has been linked to both depression [6] and ethanol drinking [7]. Studies in humans revealed that low availability of the 5-HT precursor, tryptophan, has been associated with an early onset of alcohol dependence, accompanied by depressive and aggressive symptoms [8]. A decrease in the level of 5-HT or its metabolite, 5-hydroxyindole-acetic acid (5-HIAA), has been found in the cerebrospinal fluid and plasma of some subgroups of alcoholics in the abstinence phase [9-11]. Tryptophan depletion studies in healthy individuals demonstrated that low 5-HT enhanced ethanol-induced impulsivity [12], but, in alcoholics, it did not change ethanol consumption or cue-evoked craving $[13,14]$. On the other hand, increasing 5-HT neurotransmission by selective 5-HT reuptake inhibitors (SSRIs) decreased ethanol drinking in alcoholic individuals, specifically in those with comorbid alcoholism and depression [15-17]. However, other studies showed low efficacy of SSRI treatment in alcoholism [18]. Considering the complexity of alcohol use disorder, alcoholics were subgrouped into "lower risk/severity" (type A) and "higher risk/severity" (type B) alcoholics [19], with type B having abnormalities in 5-HT transmission (i.e., a functional polymorphism in 5-HT transporter (5-HTT) gene; for review [7]). Importantly, in type B alcoholics, treatment with SSRIs, such as fluoxetine or sertraline, led to poorer drinking outcomes. However, in type A alcoholics, treatment with sertraline, but not fluoxetine, had a beneficial effect on drinking-related measures [20-22]. Such differential response of type A and B alcoholics to SSRIs suggests that further optimization of the classification of alcoholic individuals is needed to achieve the best results in alcoholism treatment using serotoninergic drugs.

Interestingly, preclinical studies have shown that selectively bred alcohol-preferring rats displayed alterations in 5-HT function; however, there is inconsistency in the direction of observed changes [23-27]. Neonatal 5-HT depletion by lesioning the 5-HT fibers by neurotoxin 5,7-dihydroxytryptamine (5,7-DHT) led to decreased ethanol intake in adult rats [28]. The same treatment of adult rats pre-exposed to ethanol either had no effect or enhanced ethanol-drinking behavior [29-32]. However, behavioral consequences of 5,7-DHT treatment may not only be due to a reduction in 5-HT level, but also to the loss of 5-HT neurons [33].

An alternative approach for assessing the role of central 5-HT neurotransmission that leaves the 5-HT neurons intact is to modulate the activity of enzymes involved in 5-HT synthesis, mainly tryptophan hydroxylase 2 (TPH2). TPH2 is responsible for the conversion of tryptophan to 5-hydroxytryptophan (5-HTP), the rate-limiting step of 5-HT production. Tph 2 mRNA is synthesized within the 5-HT neurons of the brainstem raphe nuclei and can be transported via axonal transport to other brain areas, such as the cortex, hippocampus, striatum, hypothalamus, and cerebellum [34-36]. Studies in humans revealed elevated levels of TPH2 mRNA and protein in the dorsal and median raphe nucleus of alcoholic individuals [37,38]. A study on suicide victims with major depression and alcohol dependence showed enhanced TPH-immunoreactivity only in the dorsal subnucleus of the dorsal raphe [39]. In addition, several single nucleotide polymorphisms in the human TPH2 gene have been associated with major depression (e.g., $\mathrm{R} 441 \mathrm{H} ;[40,41])$ and alcoholism (e.g., intron variant rs1386496; [42,43]); however, other investigators have failed to find the link between TPH2 gene variants and depression (for review [41]) or alcohol dependence [44,45].

Preclinical studies examining the effects of Tph2 gene variants on the level of ethanol intake have been inconsistent. For example, mice with a hypofunctional $\mathrm{R} 439 \mathrm{H}$ polymorphism in Tph2 gene (analogous to a human $\mathrm{R} 441 \mathrm{H}$ variant), leading to a partial (60-80\%) deficiency in 5-HT level in the brain [46-49], drank more ethanol-sucrose solution compared to wild-type mice [50]. In another study, the R439H Tph2 knock-in mice drank amounts of ethanol comparable to wild-type animals; however, under aversive conditions, displayed enhanced motivation for ethanol [51]. Low preference for ethanol was reported 
in two mouse strains, BALB/cJ and DBA/2A, that carry another polymorphism, C1473G (P447R) in the Tph2 gene, leading to reduction in Tph2 mRNA and protein levels and about a $15 \%$ decrease in 5-HT content in the brain [52-55].

Mice lacking TPH2 have been generated by several laboratories [56-59]. Characterization of these mice revealed a number of phenotypes associated with the loss of brain 5-HT, including early postnatal growth retardation, maternal neglect, increased aggression, sleep disturbances, social deficits, reduced anxiety-like behavior, and increased food intake [56,60-62]. Evaluation of depression-like behavior did not reveal a clear-cut phenotype. Specifically, depression-like phenotype of Tph2-deficient $\left(T p h 2^{-/-}\right)$mice was observed in the forced swim test (FST); however, no difference in behavior compared to wild-type mice was detected in tail suspension and sucrose preference tests (for review [63]). To date, the effects of complete inactivation of the Tph2 gene on ethanol-drinking behavior have not yet been studied.

Taken together, the data discussed above prompted us to test the hypothesis that the life-long 5-HT deficiency affects the initiation of ethanol drinking and ethanol-induced antidepressant effects in mice. Furthermore, in search of a molecular mechanism linking 5-HT function and ethanol addiction, we analyzed the changes in Tph2 transcript level in wild-type mice drinking ethanol. In this study, we employed Tph $2^{-/-}$mice that lack central 5-HT throughout the life [56]. We first evaluated alcohol-drinking behavior in $\mathrm{Tph} 2^{-/-}$mice that had continuous access to ethanol solutions of increasing concentrations in a two-bottle choice procedure. We next evaluated whether the genetic ablation of Tph2 affected the antidepressant effects of ethanol in the FST. In the second part of the study, we assessed Tph 2 expression in the brain of $T p h 2^{+/+}$mice drinking ethanol by quantitative real-time PCR (qPCR). We demonstrate that Tph2 deficiency in mice enhanced ethanol consumption and that $T p h 2$ transcript levels correlated with ethanol intake in mice.

\section{Materials and Methods}

\subsection{Animals}

Animal experimental procedures were carried out in accordance with the European Communities Council Directive 2010/63/UE and had been approved by the local animal welfare and ethical review body (Landesamt für Gesundheit und Soziales Berlin (LaGeSo), G 0343/09, date of approval: 24 March 2010). All the efforts were made to minimize animal suffering and to reduce the number of mice used.

Animals were maintained at the animal facility of the MDC (Berlin, Germany). Mice were housed in individually ventilated cages $(34 \mathrm{~cm} \times 19 \mathrm{~cm} \times 13 \mathrm{~cm}$; Tecniplast Deutschland, Hohenpeissenberg, Germany) in a colony room maintained at $21 \pm 1{ }^{\circ} \mathrm{C}$ under a 12-h light-dark cycle (lights on at 7:00 am). Standard rodent chow $(0.25 \%$ sodium, SSNIFF Spezialitäten, Soest, Germany) and water were available ad libitum. The behavioral experiments were conducted during the light phase (between 8:00 and 16:00) of the lightdark cycle.

Male Tph $2^{-/-}$mice on a C57BL/ 6 background (F10 generation backcross; $\left.n=14\right)[56,60]$ and wild-type mice $\left(T p h 2^{+/+} ; n=22\right)$ weighing $24.31 \pm 0.64 \mathrm{~g}$ and $23.64 \pm 0.33 \mathrm{~g}$, respectively, at the beginning of the experiment (ca. 10 weeks old) were used. To generate

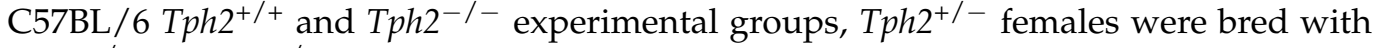
$\mathrm{Tph} 2^{-/-}$or $\mathrm{Tph} 2^{+/+}$males. Genotyping was carried out using DNA isolated from the ear snips by multiplex PCR with primers Neo3: $5^{\prime}$-CTGCGCTGACAGCCGGAACAC-3', TPH34: 5'-AGCTGAGGCAGACAGAAAGG-3' , and TPH54: 5'-CCAAAGAGCTACTCGA CCTACG-3' to distinguish the Tph2-wild-type allele (TPH54/34, 600 bp) from the Tph2knockout allele (TPH54/Neo3; 450 bp).

\subsection{Behavioral Studies}

\subsubsection{Drugs}

Ethanol (3, 6, or 10\%; v/v diluted from 96\% ethyl alcohol; Merck, Darmstadt, Germany) was dissolved in tap water. 


\subsubsection{Two-Bottle Free-Choice Ethanol Consumption}

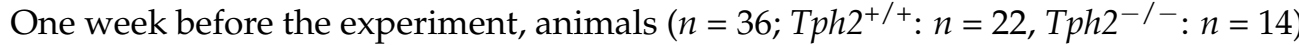
were single housed and habituated to two bottles (one empty and the second filled with water). The position of bottles was changed from the left to the right side to induce seeking behaviors in animals. After 6 days, randomly assigned mice were exposed to a two-bottle free-choice paradigm (water and ethanol; $n=26 ; \mathrm{Tph}^{+/+}: n=17, \mathrm{Tph} 2^{-/-}: n=9$ ) in home cages for 29 days, using increasing concentrations of ethanol solution $(3 \% v / v, 4$ days; $6 \%$ $v / v, 4$ days; $10 \% v / v, 21$ days) [64-67]. Animals exposed to two bottles of water throughout the study were used as controls $\left(n=10 ; T p h 2^{+/+}: n=5, T p h 2^{-/-}: n=5\right)$. Every two days, the bottles were refilled with ca. $14 \mathrm{~mL}$ of fresh solutions and the position of the bottles was alternated to control for side preference. Liquid (alcohol and water) intake was measured by weighing the bottles in 2-day trials (after $48 \mathrm{~h}$ ) for 28 days and on the final day of experiment (day 29) after $24 \mathrm{~h}$. Ethanol intake was calculated as g of pure ethanol per $\mathrm{kg}$ of body weight per 1 or 2 days $(\mathrm{g} / \mathrm{kg})$. Preference was calculated as $\mathrm{g}$ of ethanol solution consumed within 1 or 2 days per total amount of liquid (\%). Cumulative ethanol intake was calculated as $\mathrm{g}$ of pure ethanol per $\mathrm{kg}$ of body weight within 29 days $(\mathrm{g} / \mathrm{kg} / 29 \mathrm{~d})$. We also calculated the average intake of ethanol $(\mathrm{g} / \mathrm{kg} / \mathrm{d})$, preference $(\%)$, and average total liquid intake ( $\mathrm{mL}$ of total liquid (water or water + ethanol) consumed per $\mathrm{kg}$ of body weight per day $(\mathrm{mL} / \mathrm{kg} / \mathrm{d}))$ during the initial 4 days of each ethanol concentration.

\subsubsection{Forced Swim Test (FST)}

Immediately after the end of the last ethanol exposure day, mice were introduced to the FST. As previously described $[60,68,69]$, mice were individually placed in a plastic beaker ( $24 \mathrm{~cm}$ high and $17.5 \mathrm{~cm}$ in diameter) filled with $18 \mathrm{~cm}$ of water $\left(23 \pm 1{ }^{\circ} \mathrm{C}\right)$. The following parameters were scored manually in 2-min intervals for $6 \mathrm{~min}$ (the "pretest": 0-2 min, "test": 2-6 min): latency to the first immobility episode, immobility, swimming, and climbing. Latency was defined as the time that elapsed between placing the mouse in the beaker and the first immobility episode. A mouse was rated immobile if it was floating on the water, making only movements necessary to keep its head above water. Swimming was defined as horizontal movements of four legs or just the hindlimbs. Climbing was scored when the mouse was making struggling vertical movements of the forepaws, directed against the wall of the beaker [70]. After the test, mice were then removed from the water, dried with towels, and placed in a warm enclosure before they were returned to their home cages. The beakers were emptied and cleaned between mice.

\subsection{Molecular Analyses}

2.3.1. Tph2 Gene Expression Analysis in "High Ethanol-Drinking" and "Low Ethanol-Drinking" Mice

For the Tph2 gene expression analysis, only the brain tissue from $T p h 2^{+/+}$mice $(n=22$; water group: $n=5$, or water/ethanol group: $n=17$ ) was taken. First, the Tph2 expression level in the whole group of $T p h 2^{+/+}$mice drinking ethanol $(n=17)$ was compared with water-drinking mice $(n=5)$.

Since there was considerable variability in the level of ethanol intake and preference for ethanol among Tph2 $2^{+/+}$mice during the experiment, the level of Tph2 expression was then analyzed with respect to the animals' ethanol intake levels in two drinking periods: during the initial days of ethanol drinking (i.e., the first 12 days of drinking different concentrations of ethanol) or during the last week of access to ethanol (period of stabilized ethanol drinking). For each period (analyzed separately), the average ethanol intake $(\mathrm{g} / \mathrm{kg} / \mathrm{d})$ was calculated for each animal. In addition, an average preference (\%) was calculated for each animal for each of the tested periods. The average ethanol intake scores were used to divide mice into "high ethanol-drinking" $(n=9)$ and "low ethanoldrinking" $(n=8)$ animals using a median split [71], i.e., animals with values of ethanol intake below the median were classified as low drinkers, while animals' scores equal to or greater than the median were considered as high drinkers. For each analyzed period, 
the transcript levels of "high ethanol-drinking" mice were compared with those of "low ethanol-drinking" animals.

Such analysis between ethanol intake levels in mice, classified as high- or low-ethanol drinkers at different drinking periods, and Tph2 expression was aimed at examining whether the inter-individual differences in Tph 2 mRNA levels were notable prior to ethanol exposure (assuming that ethanol did not affect Tph2 expression) or were a result of the long-term exposure of animals to alcohol.

\subsubsection{Sample Preparation}

Immediately after the end of the FST, animals were sacrificed under non-stressful conditions by quick decapitation and the brains were rapidly dissected and chilled in ice-cold saline. Raphe nuclei of the brainstem, hippocampus (including the dentate gyrus, CA3, CA2, CA1, and subiculum), and the prefrontal cortex were dissected according to the Mouse Brain Atlas [72]. Brain tissue was preserved in RNAlater RNA Stabilization Reagent (QIAGEN, Erlangen, Germany), frozen on dry ice, and stored at $-80^{\circ} \mathrm{C}$ to prevent degradation of RNA.

Total RNA was isolated from the above brain areas using a phenol-based method (TRIzol Reagent; Invitrogen, Darmstadt, Germany). Further RNA cleanup and on-column DNase digestion were performed using RNeasy Mini Kit (QIAGEN, Hilden, Germany) according to the manufacturer's instructions. RNA quantification and purity were assessed using NanoDrop ${ }^{\mathrm{TM}}$ spectrophotometer ND-1000 (Peqlab, Erlangen, Germany). A total of $1 \mu \mathrm{g}$ of isolated RNA was reverse transcribed using random hexamer primers and Moloney Murine Leukemia Virus Reverse Transcriptase (M-MLV RT; Invitrogen). The samples were then processed for qPCR to assess the expression of Tph2.

\subsubsection{Real-Time PCR}

Gene expression analysis was performed by qPCR using ABI Prism 7900 HT Fast RT-PCR System (Applied Biosystems, Darmstadt, Germany) with GoTaq qPCR Master Mix (A600A PROMEGA, Madison, WI, USA), $22.5 \mathrm{ng}$ of cDNA, and the following primers: Tph2 (NM_173391.3): SAB-RT_mTPH2_FW: 5'-GTCAATTACCCGTCC CTTCTC3'; SAB-RT_mTPH2_REV: 5'-TTATTCAAGGCATCACACACTG-3' (product length: 138 bp); a housekeeping gene, TATA box binding protein (Tbp; NM_013684.3): forward $5^{\prime}$ CCCTATCACTCCTGCCACACC-3'; reverse 5'-CGAAGTGCAATGGTCTTT AGGTC- $3^{\prime}$ (product length: $117 \mathrm{bp}$ ). For each tested brain region, standard curves with serial dilutions of cDNAs were performed to analyze the efficiency of the primers. Samples were run in triplicates in 384-well plate formats. A negative control lacking cDNA was included for each primer pair. All the data were normalized to the mRNA level of Tbp. To show differential expression of Tph 2 in the brain of control mice, the abundance of Tph 2 mRNA was calculated according to the following equation:

$$
\text { abundance }=2^{-C_{\mathrm{T}}} \text {. }
$$

In the analysis of the effects of ethanol on Tph2 transcript level, a comparative cycle threshold $\left(C_{\mathrm{T}}\right)$ method $\left(2^{-\Delta \Delta C_{\mathrm{T}}}\right.$ method; [73]) was used. Results are shown as fold change $\left(2^{-\Delta \Delta C_{\mathrm{T}}}\right)$ means of the gene of interest.

\subsection{Statistical Analyses}

Data are expressed as the means ( \pm SEM) or median and percentile range. The normality of data distribution was tested by the Shapiro-Wilk normality test. After checking all the assumptions (i.e., normal distribution, equality of variance), the appropriate statistical tests were applied. Student's $t$-test for independent samples was used to study comparisons between means representing changes from the control values (e.g., Tph 2 transcript level analyses). In the case of the occurrence of unequal variances, Student's $t$-test with Welch correction was used. In the case of the data in which the data distribution was not normal, a Mann-Whitney U test was used. A two-way repeated-measures analysis of variance 
(ANOVA) was used to analyze the liquid (or water) intake measurements (factors: genotype, treatment (ethanol), ethanol concentration). One-way repeated-measures ANOVA was used to process ethanol consumption and preference data (factors: genotype, day) of the 2-day measurements performed over 28 days of the experiment. Two-way ANOVA was used to analyze the FST data (factors: genotype, treatment (ethanol)). One-way ANOVA was used to verify differences in Tph2 transcript level between different brain regions, and between "high ethanol-drinking" and "low ethanol-drinking" mice. ANOVA was followed by a post hoc Newman-Keuls test. All comparisons were made with an experiment type I error rate $(\alpha)$ set at $p<0.05$.

\section{Results}

\subsection{Tph2 Deficiency Leads to Increased Ethanol Consumption in Mice}

We first evaluated the ethanol drinking behavior in Tph $2^{-/-}$and $T p h 2^{+/+}$mice with continuous access to increasing ethanol concentrations in a two-bottle choice procedure.

The body weight of Tph $2^{-/-}$mice was similar to $T p h 2^{+/+}$animals at the beginning of the experiment $\left(T p h 2^{+/+}: 23.64 \pm 0.33 \mathrm{~g}, \mathrm{Tph}^{-/-}: 24.31 \pm 0.64 \mathrm{~g} ; \mathrm{t}=1.03, \mathrm{df}=34, p=0.31\right.$, $\left.\eta^{2}=0.03\right)$.

ANOVA analyses revealed that the effect of Tph2 deficiency on ethanol consumption with a two-bottle choice paradigm did not change according to drinking days (no effect of genotype $x$ day interaction $\left(\mathrm{F}(13,312)=1.40, p=0.16, \eta p^{2}=0.055\right)$; Figure $\left.1 \mathrm{~A}\right)$. However, there was a significant effect of genotype $\left(\mathrm{F}(1,24)=9.58, p=0.0049, \eta \mathrm{p}^{2}=0.29\right)$ and day $\left(\mathrm{F}(13,312)=6.03, p<0.001, \eta \mathrm{p}^{2}=0.20\right)$ on the level of ethanol consumption during the chronic exposure of Tph $2^{-/-}$mice to ethanol (Figure 1A), indicating that both factors, independent of one another, affected ethanol intake in mice.

A
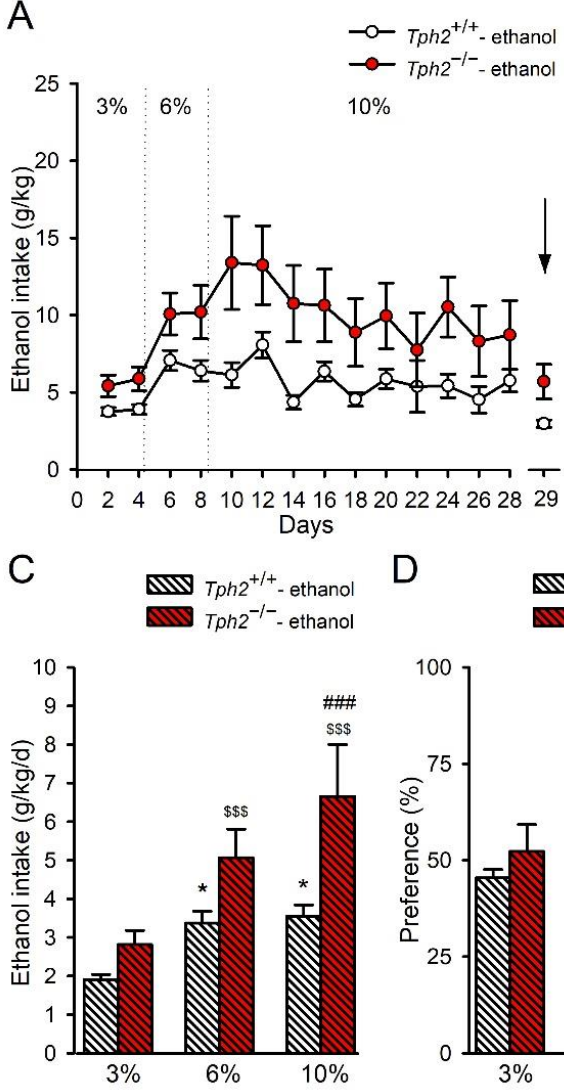

D

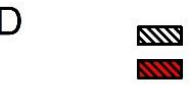

$T p h 2^{+/+}$- ethanol
$T p h 2^{-l_{-}}$- ethanol

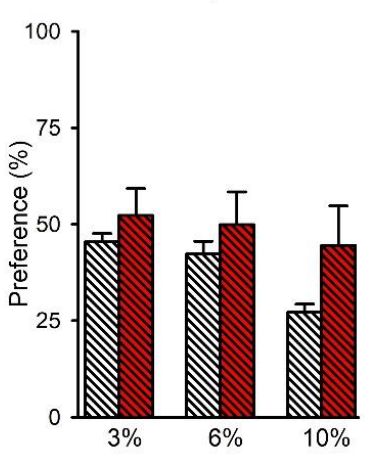

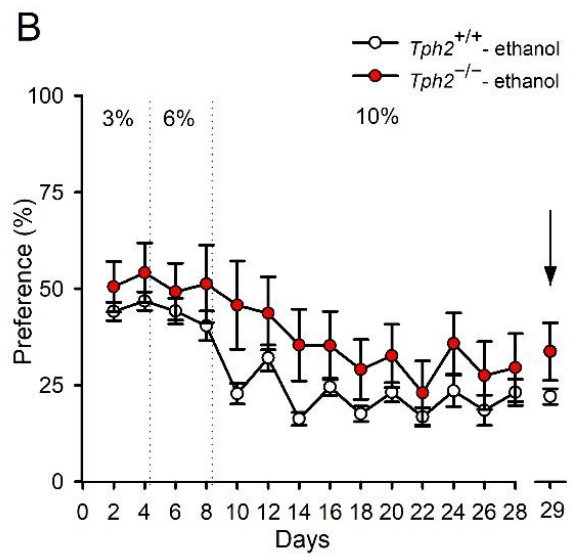

E

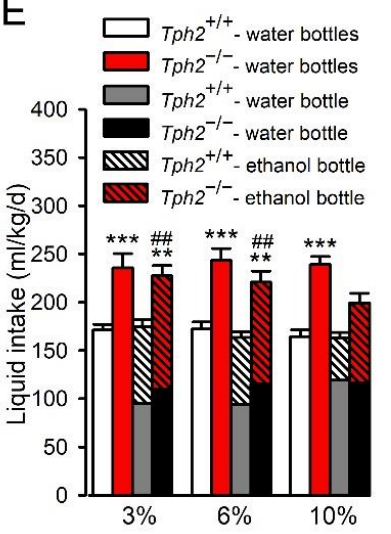

Figure 1. Ethanol consumption in Tph $2^{-/-}$deficient mice in a two-bottle choice test. Mice were exposed to a two-bottle (water and ethanol) free-choice paradigm in home cages for 29 days (ethanol: 
$3 \% v / v, 4$ days; $6 \% v / v, 4$ days; $10 \% v / v, 21$ days). Animals that were given access to two bottles of water were used as controls. Liquid (alcohol and water) intake was measured by weighing the bottles in 2-day trials for 28 days. On the final day of ethanol drinking (day 29), liquid intake was measured after $24 \mathrm{~h}$, and mice were introduced to the forced swim test (FST). Immediately after the test, animals were killed by decapitation (black arrow) and the brain tissue was collected. The following parameters were measured: (A) ethanol intake- $\mathrm{g}$ of pure ethanol consumed per $\mathrm{kg}$ of body weight per 1 or 2 days, $(\mathrm{g} / \mathrm{kg})$; (B) preference-g of ethanol solution consumed per total amount of liquid, \%; (C) average intake of ethanol during the first 4 days of each concentration of ethanol, $(\mathrm{g} / \mathrm{kg} / \mathrm{d})$; (D) preference during 4 days of each concentration of ethanol, \%; (E) average intake of total liquid during 4 days of each concentration of ethanol- $\mathrm{mL}$ of total liquid (water or water + ethanol) consumed per $\mathrm{kg}$ of body weight per day, $(\mathrm{mL} / \mathrm{kg} / \mathrm{d})$. The data are expressed as the means ( \pm SEM) of the data from 5-17 mice/group. (A) genotype effect: $p<0.01$, day effect: $p<0.001$; (B) day effect: $p<0.001$; (C) post hoc Newman-Keuls: ${ }^{*} p<0.05$ vs. Tph $2^{+/+}$- ethanol (3\%); $\$ \$ p<0.001$ vs. Tph $2^{-/-}$- ethanol (3\%); ${ }^{\# \#} p<0.001$ vs. Tph $2^{+/+}$- ethanol (10\%); (D) ethanol dose effect: $p<0.001$ $10 \%$ ethanol vs. $3 \%$ or $6 \%$; (E) liquid intake: post hoc Newman-Keuls: ${ }^{* *} p<0.01,{ }^{* * *} p<0.001$ vs. appropriate $\mathrm{Tph} 2^{+/+}$- water group; ${ }^{\# \#} p<0.01$ vs. appropriate $\mathrm{Tph} 2^{+/+}$- ethanol group. Water intake: genotype effect: $p<0.01$, treatment effect: $p<0.001$.

There was a significant increase in cumulative (during 29 days) ethanol intake in Tph $2^{-/-}$mice in comparison to Tph $2^{+/+}$mice $\left(T p h 2^{+/+}: 80.53 \pm 4.57(\mathrm{~g} / \mathrm{kg} / 29 \mathrm{~d}), \mathrm{Tph}^{-/-^{-}}\right.$: $\left.139.45 \pm 24.80(\mathrm{~g} / \mathrm{kg} / 29 \mathrm{~d}) ; \mathrm{t}=2.34, \mathrm{df}=8.55, p=0.046, \eta^{2}=0.39\right)$.

ANOVA analyses showed that the effect of Tph2 deficiency in mice on preference for ethanol did not change depending on ethanol drinking days (no effect of genotype $x$ day interaction $\left(\mathrm{F}(13,312)=0.92, p=0.53, \eta \mathrm{p}^{2}=0.037\right)$; Figure $\left.1 \mathrm{~B}\right)$. However, there was a significant effect of drinking days $\left(\mathrm{F}(13,312)=15.61, p<0.001, \eta \mathrm{p}^{2}=0.39\right)$, but not genotype $\left(\mathrm{F}(1,24)=3.79, p=0.063, \eta \mathrm{p}^{2}=0.14\right)$, on the preference for ethanol (Figure 1B), indicating that preference for ethanol, independent of genotype, was changed throughout days.

Further data analysis revealed that the effect of Tph 2 deficiency on the average intake of ethanol during 12 initial days (4 initial days of each ethanol concentration) of ethanol drinking changed according to different ethanol concentrations (a significant effect of genotype $x$ ethanol dose interaction $\left(\mathrm{F}(2,48)=4.76, p=0.013, \eta \mathrm{p}^{2}=0.17\right)$, genotype $\left(\mathrm{F}(1,24)=9.68, p=0.0048, \eta \mathrm{p}^{2}=0.29\right)$, and ethanol concentration $(\mathrm{F}(2,48)=29.94, p<0.001$, $\left.\eta \mathrm{p}^{2}=0.56\right)$; Figure $1 \mathrm{C}$ ). Post hoc Newman-Keuls analysis showed that consumption of 6 and $10 \%$ ethanol in $\mathrm{Tph} 2^{+/+}$mice was significantly increased compared to the $3 \%$ ethanol concentration by 76 and $86 \%$, respectively ( $p=0.018$ and 0.012 , respectively; Figure $1 C$ ). In addition, Tph $2^{-/-}$mice exhibited increased by $80 \%$ consumption of $6 \%$ ethanol and increased by $136 \%$ consumption of $10 \%$ ethanol in comparison to the consumption of $3 \%$ ethanol ( $p=0.00048$ and 0.00013, respectively; Figure 1C). Importantly, Tph2 $2^{-}$mice drank significantly more $10 \%$ ethanol than Tph2 $2^{+/+}$animals $(p=0.00046$; Figure $1 \mathrm{C})$.

ANOVA analyses showed that the effect of depletion of brain 5-HT in Tph $2^{-/-}$mice on preference for ethanol during the first 12 days of exposure did not change depending on ethanol concentrations (no effect of genotype $x$ ethanol dose interaction $(\mathrm{F}(2,48)=1.96$, $p=0.15, \eta p^{2}=0.076$; Figure 1D). However, the analysis demonstrated a significant effect of ethanol concentration $\left(\mathrm{F}(2,48)=10.75, p=0.00014, \eta \mathrm{p}^{2}=0.31\right)$, but not genotype $\left(\mathrm{F}(1,24)=2.87, p=0.10, \eta \mathrm{p}^{2}=0.11\right)$, on the preference for ethanol (Figure 1D). NewmanKeuls test of the main effect of ethanol concentration revealed a significant reduction in preference in all animals drinking 10\% ethanol compared to mice drinking 3\% $(p=0.00014)$ or $6 \%(p=0.00024)$ ethanol (Figure 1D).

As estimated, during 12 initial days of ethanol drinking, the effect of Tph 2 deficiency in mice significantly altered average liquid (ethanol + water) intake according to treatment and ethanol concentration (a significant effect of genotype $\mathrm{x}$ treatment (ethanol) $\mathrm{x}$ ethanol dose interaction $\left(\mathrm{F}(2,64)=3.81, p=0.027, \eta \mathrm{p}^{2}=0.11\right)$; Figure 1E). There was a significant effect of genotype $\left(\mathrm{F}(1,32)=39.51, p<0.001, \eta \mathrm{p}^{2}=0.55\right)$ and ethanol concentration $\left(\mathrm{F}(2,64)=8.71, p=0.00045, \eta \mathrm{p}^{2}=0.21\right)$, but no effect of ethanol treatment $(\mathrm{F}(1,32)=1.84$, 
$\left.p=0.19, \eta p^{2}=0.054\right)$ on total liquid consumption (Figure 1E). Newman-Keuls analysis demonstrated that, in comparison to water-drinking $T p h 2^{+/+}$animals, a significant increase in average liquid intake was reported in Tph $2^{-/-}$mice with access to two bottles of water during the first 4 days of exposure to $3 \%(p=0.00097), 6 \%(p=0.00038)$ and $10 \%$ $(p=0.00028)$ ethanol. Importantly, in Tph2 ${ }^{-/-}$mice drinking ethanol and water, total liquid intake was enhanced only during the four initial days of exposure to $3 \%(p=0.0035)$ and $6 \%(p=0.0071)$, but not to $10 \%(p=0.12)$, ethanol compared to appropriate $\mathrm{Tph} 2^{+/+}$water groups (Figure 1E). Total liquid consumption in Tph $2^{-/-}$mice exposed to $3-6 \%$, but not to $10 \%$, ethanol was significantly higher than that of $T p h 2^{+/+}$animals drinking ethanol $(p=0.0030$ and $p=0.0040$, respectively; Figure 1E).

As estimated during the 12 initial days of ethanol drinking, the effect of 5-HT depletion in $T p h 2^{-/-}$mice on average water intake did not change according to treatment or ethanol concentration (no effect of genotype $\mathrm{x}$ treatment (ethanol) $\mathrm{x}$ ethanol dose interaction $\left(\mathrm{F}(2,64)=1.28, p=0.28, \eta p^{2}=0.038\right) ;$ Figure $\left.1 \mathrm{E}\right)$. However, there was a significant effect of genotype $\left(\mathrm{F}(1,32)=9.89, p=0.0036, \eta p^{2}=0.24\right)$ and ethanol treatment $(\mathrm{F}(1,32)=55.23$, $\left.p<0.001, \eta p^{2}=0.63\right)$, but no effect of ethanol concentration $(\mathrm{F}(2,64)=0.92, p=0.40$, $\eta p^{2}=0.028$ ), on water consumption (Figure 1E). This analysis implied that both genotype and ethanol treatment, independent of the other factor, influenced the average water intake in mice, i.e., Tph 2 deficiency increased, whereas ethanol exposure reduced, water intake (Figure 1E).

Overall, increasing the ethanol concentrations (6-10\%) enhanced ethanol intake in both genotypes, with the highest $(10 \%)$ concentration inducing a significantly higher ethanol

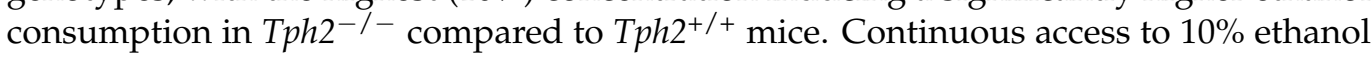
decreased preference for ethanol, independent of the genotype group. During the first days of exposure to each ethanol concentration, average liquid consumption was increased

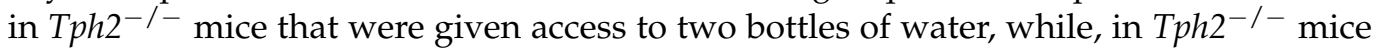
drinking ethanol, total liquid intake was enhanced only when mice were exposed to lower (3-6\%) ethanol concentrations. Continuous access to ethanol reduced average water intake in both genotypes.

\subsection{Ethanol Exposure in Tph2-/- Mice Induces Antidepressant Effects}

We next evaluated whether the genetic ablation of Tph2 affected the antidepressant effects of ethanol. As measured in the FST, the effect of Tph2 deficiency in mice on the latency to the first immobility episode did not change according to ethanol exposure (no effect of genotype $x$ treatment interaction $\left(F(1,32)=0.069, p=0.79, \eta p^{2}=0.0021\right)$; Figure 2A). There was no effect of genotype $\left(\mathrm{F}(1,32)=2.29, p=0.14, \eta p^{2}=0.067\right)$ or treatment $(\mathrm{F}(1,32)=0.057$, $p=0.81, \eta p^{2}=0.0018$ ) on latency parameter (Figure $2 \mathrm{~A}$ ).

Two-way ANOVA analysis of the immobility time during the first 2-min ("pretest") measurement period revealed a significant effect of genotype $\mathrm{x}$ treatment interaction $\left(\mathrm{F}(1,32)=4.17, p=0.049, \eta \mathrm{p}^{2}=0.12\right)$, but no effect of genotype $(\mathrm{F}(1,32)=1.91, p=0.18$, $\left.\eta p^{2}=0.056\right)$ or treatment $\left(F(1,32)=0.99, p=0.33, \eta p^{2}=0.030\right)$, on immobility. However, the post hoc Newman-Keuls showed no significant changes between the genotypes $(p>0.05$; Figure 2B).

Statistical analyses demonstrated that the effect of Tph2 deficiency on swimming behavior in the FST during an initial 0-2 min did not alter according to ethanol treatment (no effect of genotype $x$ treatment interaction $\left(F(1,32)=1.87, p=0.18, \eta p^{2}=0.055\right)$; Figure $2 B$ ). However, there was a significant effect of genotype $\left(F(1,32)=11.44, p=0.0019, \eta p^{2}=0.26\right)$, but not ethanol treatment $\left(\mathrm{F}(1,32)=0.13, p=0.72, \eta \mathrm{p}^{2}=0.0041\right)$, on swimming during the 0-2-min measurement (Figure 2B). This analysis indicated that Tph2 gene inactivation reduced swimming behavior in mice. 


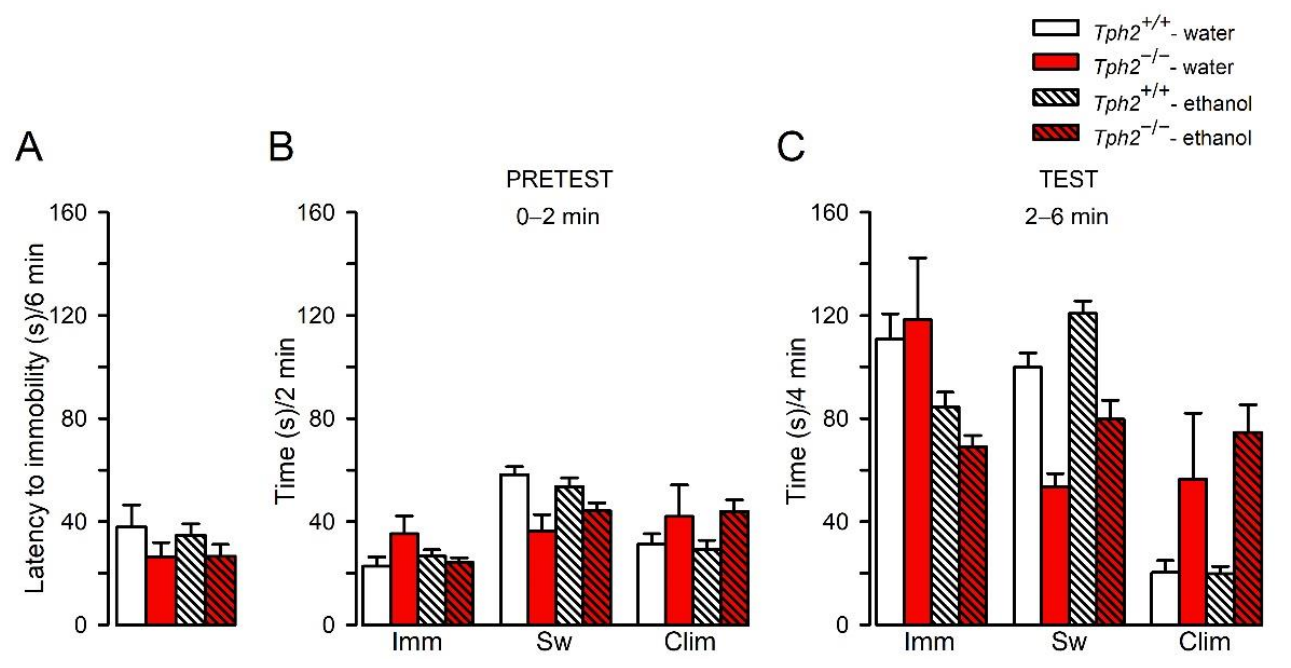

Figure 2. Effects of ethanol consumption in Tph2 $2^{-/-}$mice on the behavior in the FST. Following 29 days of exposure to the increasing concentrations of ethanol, the animals were individually placed in a beaker filled with water, and the following parameters were measured in 2-min intervals for 6 min: (A) latency to immobility, and immobility (Imm), swimming (Sw), and climbing (Clim) during (B) "PRETEST": 0-2 min and (C) "TEST": 2-6 min. The results are shown as the means ( \pm SEM) of data from 5-17 mice/group. (B) "Sw": genotype effect: $p<0.01$; “Clim": genotype effect: $p<0.05$. (C) "Imm": treatment effect: $p<0.001$; "Sw": genotype effect: $p<0.001$, treatment effect: $p<0.01$; "Clim": genotype effect: $p<0.001$.

The effect of genetic inactivation of Tph2 in mice on climbing behavior during the 0-2-min time interval did not alter depending on the exposure to ethanol (no effect of genotype $x$ treatment interaction $\left(\mathrm{F}(1,32)=0.12, p=0.73, \eta \mathrm{p}^{2}=0.0037\right)$; Figure $\left.2 \mathrm{~B}\right)$. However, there was a significant effect of genotype $\left(\mathrm{F}(1,32)=4.47, p=0.042, \eta \mathrm{p}^{2}=0.12\right)$, but not ethanol treatment $\left(\mathrm{F}(1,32)=0.0001, p=0.99, \eta \mathrm{p}^{2}=0.000002\right)$, on climbing behavior during the 0-2-min measurement (Figure 2B). This indicated that Tph2 deficiency enhanced climbing behavior in mice.

Throughout the "test" (during a 2-6-min measurement), the effect of Tph2 deficiency on the immobility time did not change according to ethanol intake (no effect of genotype $x$ treatment interaction $\left(\mathrm{F}(1,32)=1.20, p=0.28, \eta \mathrm{p}^{2}=0.036\right.$; Figure $\left.2 \mathrm{C}\right)$. A significant effect of ethanol exposure $\left(\mathrm{F}(1,32)=13.53, p=0.00086, \eta \mathrm{p}^{2}=0.3\right)$, but not genotype $(\mathrm{F}(1,32)=0.14$, $\left.p=0.71, \eta p^{2}=0.0044\right)$, on the immobility parameter was detected (Figure $2 \mathrm{C}$ ), implying that ethanol consumption reduced immobility in both genotypes.

The analyses revealed that the effect of Tph2 deficiency on swimming time did not alter according to ethanol exposure (no effect of genotype $x$ treatment interaction $(F(1,32)=0.13$, $p=0.72, \eta \mathrm{p}^{2}=0.004$; Figure $\left.2 \mathrm{C}\right)$. However, a significant effect of genotype $(\mathrm{F}(1,32)=37.24$, $\left.p=0.000001, \eta p^{2}=0.54\right)$ and ethanol $\left(\mathrm{F}(1,32)=10.90, p=0.0024, \eta p^{2}=0.25\right)$ on swimming were found (Figure 2C). The analysis indicated that Tph2 deficiency reduced, whereas ethanol consumption significantly increased, swimming parameter.

As for the climbing behavior, the effect of Tph2 deficiency in mice did not change according to ethanol consumption (no effect of genotype $x$ treatment interaction $(F(1,32)=0.82$, $\left.p=0.37, \eta p^{2}=0.025\right)$; Figure $\left.2 \mathrm{C}\right)$. However, a significant effect of genotype $(\mathrm{F}(1,32)=19.23$, $\left.p=0.00012, \eta p^{2}=0.38\right)$, but not treatment $\left(\mathrm{F}(1,32)=0.72, p=0.40, \eta p^{2}=0.022\right)$, on climbing time was reported (Figure 2C), suggesting that Tph2 deficiency, by itself, elevated climbing behavior.

Taken together, Tph2 deficiency induced a decrease in swimming and an increase in climbing behavior, without alterations in immobility time. Depletion of brain 5-HT had no effect on ethanol-induced antidepressant phenotype measured as a decrease in immobility time and an increase in swimming in the FST in mice. 


\subsection{Wild-Type "High Ethanol-Drinking" Mice Display Alterations in Tph2 Expression Pattern Compared to "Low Ethanol-Drinking" Animals}

In search of a mechanistic link between 5-HT synthesis and alcohol intake in mice, we investigated whether Tph2 expression is affected by ethanol exposure in wild-type animals. One-way ANOVA analysis showed that the level of Tph2 transcripts in the raphe nuclei, hippocampus, and prefrontal cortex of control mice was significantly different $\left(\mathrm{F}(2,12)=199.99, p<0.001, \eta \mathrm{p}^{2}=0.97\right.$; Figure 3A). Newman-Keuls analysis revealed that the amount of Tph 2 mRNA in the hippocampus and prefrontal cortex in control animals was 86- and 145-fold, respectively, lower than in the raphe nuclei $(p=0.00017$ and $p=0.00019$, respectively; Figure 3A). There was no difference in Tph2 transcript levels between the hippocampus and prefrontal cortex of the wild-type mice ( $p=0.94$; Figure $3 \mathrm{~A})$.
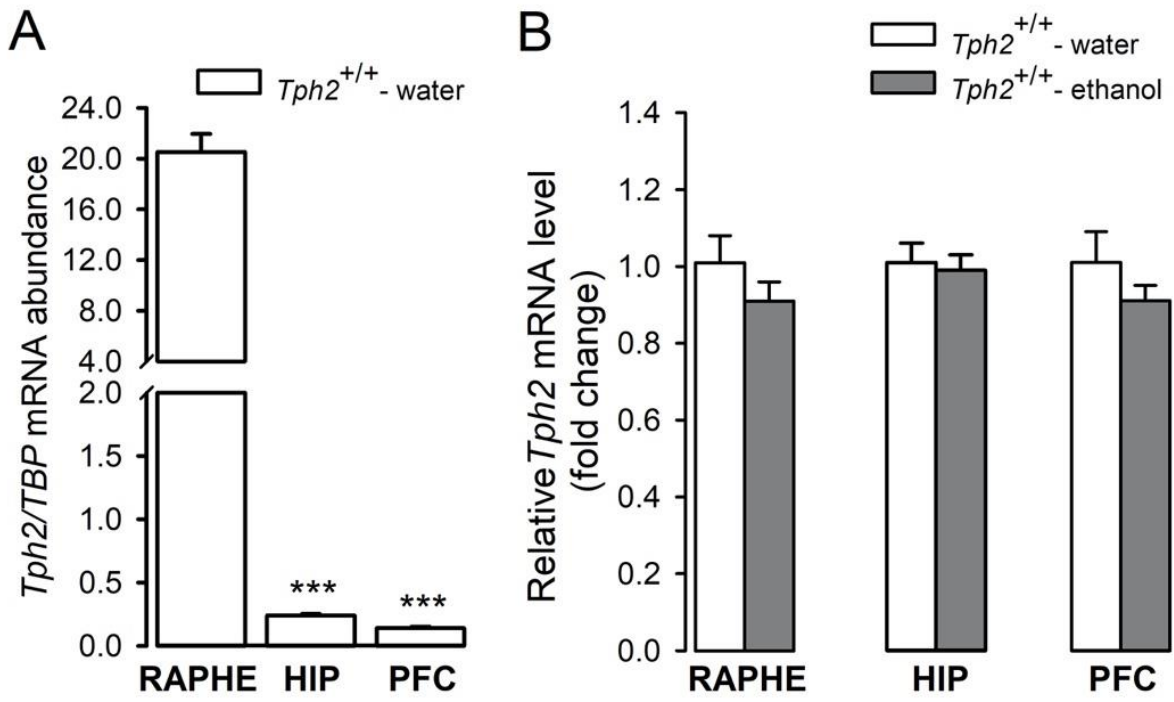

Figure 3. Effects of chronic ethanol consumption on the transcript levels of Tph2 in the selected mouse brain structures. Tph2 $2^{+/+}$mice were exposed to increasing concentrations of ethanol (3-10\%) for 29 days. Animals that were given access to two bottles of water were used as controls. On the last day of ethanol drinking, mice were introduced to the FST and, after the test, they were immediately killed by decapitation. The Tph 2 transcript level was analyzed in the raphe nuclei (RAPHE), hippocampus (HIP), and prefrontal cortex (PFC) by RT-qPCR. All the data were normalized to a housekeeping gene, TATA box binding protein (Tbp). To show differential expression of Tph 2 in the brain of control mice, the abundance of Tph 2 mRNA was calculated (A). In the analysis of the effects of ethanol on Tph2 transcript level (B), results were shown as fold change $\left(2^{-\Delta \Delta C_{\mathrm{T}}}\right)$ to control mice. Data are presented as means of data from 5-17 mice/group. (A): post hoc Newman-Keuls: ${ }^{* * *} p<0.001$ vs. Tph $2^{+/+}$-water (RAPHE).

Based on the data obtained from all $\mathrm{Tph} 2^{+/+}$mice drinking ethanol, no change in the expression level of Tph2 gene was observed in the raphe nuclei $(\mathrm{t}=1.08, \mathrm{df}=20, p=0.29$, $\left.\eta^{2}=0.055\right)$, hippocampus $(\mathrm{U}=34.50, p=0.55)$, or prefrontal cortex $(\mathrm{t}=1.18, \mathrm{df}=20, p=0.25$, $\left.\eta^{2}=0.065\right)$ compared to mice drinking water (Figure 3B).

We next analyzed the Tph2 expression level in the raphe nuclei, hippocampus, and prefrontal cortex of mice divided on "low ethanol-drinking" and "high ethanol-drinking" animals based on the average level of ethanol intake during the initial 12 days and the last week of access to ethanol.

During the first 12 days of drinking different concentrations of ethanol, "high ethanoldrinking" mice displayed an increased average ethanol intake $(t=5, \mathrm{df}=15, p=0.0002$, $\left.\eta^{2}=0.63\right)$ and preference $\left(t=2.97, \mathrm{df}=15, p=0.0095, \eta^{2}=0.37\right)$ compared to "low ethanol-drinking" animals (Figure 4A). One-way ANOVA analyses of Tph2 expression levels revealed that, in this period, there was no difference in the Tph2 transcript level in the raphe nuclei $\left(\mathrm{F}(2,19)=0.58, p=0.57, \eta p^{2}=0.058\right)$, hippocampus $(\mathrm{F}(2,19)=0.065, p=0.94$, 
$\left.\eta p^{2}=0.0068\right)$, and prefrontal cortex $\left(F(2,19)=0.67, p=0.52, \eta p^{2}=0.066\right)$ in these groups of mice (Figure 4B).

$A$

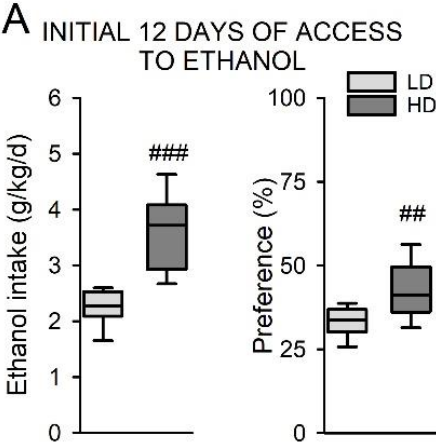

C
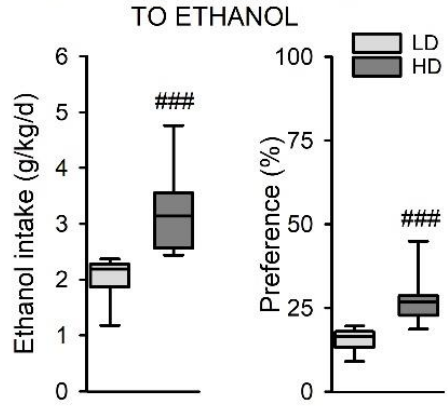

B
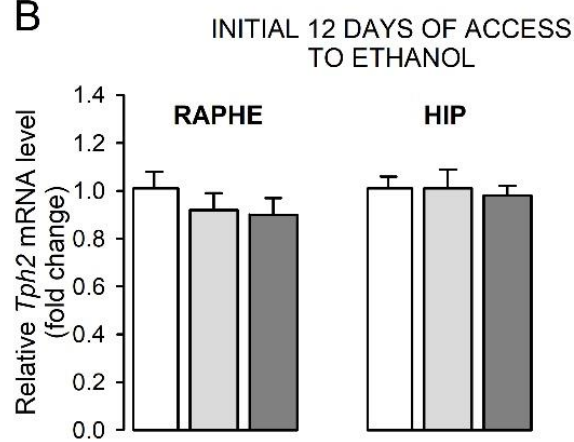

HIP
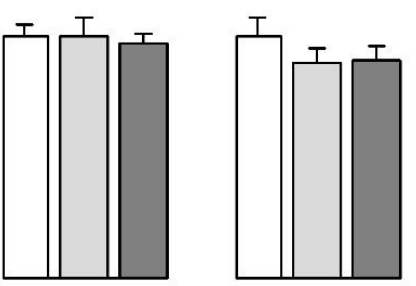

D

LAST WEEK OF ACCESS TO ETHANOL

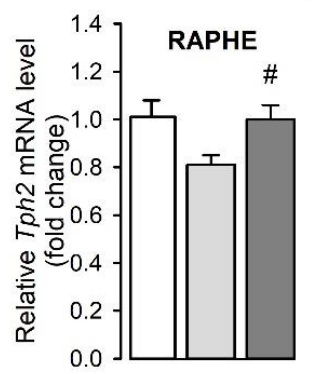

HIP

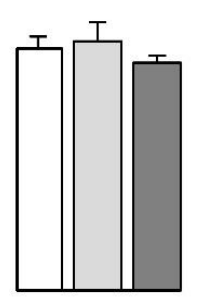

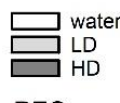

PFC

Figure 4. Transcript level of Tph2 in the brain of "high ethanol-drinking" and "low ethanol-drinking" mice over different experimental periods. Tph $2^{+/+}$mice were exposed to increasing concentrations of ethanol (3-10\%) for 29 days. Animals that were given access to two bottles of water were used as controls. On the last day of ethanol drinking, mice were introduced to the FST and, after the test, they were immediately killed by decapitation. The Tph2 transcript level was analyzed in the raphe nuclei (RAPHE), hippocampus (HIP), and prefrontal cortex (PFC) by RT-qPCR. For each investigated period- $(\mathbf{A}, \mathbf{B})$ an initial 12 days of access to ethanol and $(\mathbf{C}, \mathbf{D})$ the last week of access to ethanolmice were divided into "high ethanol-drinking" (HD) and "low ethanol-drinking" (LD) mice based on individual differences in the average ethanol intake levels. For each analyzed period, average ethanol intake $(\mathrm{g} / \mathrm{kg} / \mathrm{d})$ and average preference for ethanol (\%) were calculated for HD and LD groups $(\mathbf{A}, \mathbf{C})$. The Tph2 transcript levels were then compared between HD and LD mice (B,D). As a control, the Tph2 mRNA level for mice drinking water was used. (A,C): Data are shown as box plots, in which the horizontal line depicts the median, and vertical boxes and whiskers correspond to the percentile range. $n=8-9$ mice/group. (B,D): All RT-qPCR data were normalized to a housekeeping gene, TATA box binding protein (Tbp), and represent fold change $\left(2^{-\Delta \Delta C_{\mathrm{T}}}\right)$ means of data from 5-9 mice/group. (A): $t$-test: ${ }^{\# \#} p<0.01,{ }^{\# \# \#} p<0.001$ vs. LD. (C): Mann-Whitney U test: ${ }^{\# \# \#} p<0.001$ vs. LD. (D): RAPHE: post hoc Newman-Keuls: ${ }^{\#} p<0.05$ vs. LD; PFC: post hoc Newman-Keuls: ${ }^{*} p<0.05$ vs. water, ${ }^{\#} p<0.05$ vs. LD.

The analysis of ethanol intake data from the last week of the ethanol exposure showed that "high ethanol-drinking" mice exhibited an increase in average ethanol intake (U $=0$, $p<0.0001)$ and preference ( $\mathrm{U}=1, p=0.0002$ ) compared to "low ethanol-drinking" animals (Figure 4C). The one-way ANOVA analysis revealed that the Tph2 transcript level in the raphe nuclei of "high ethanol-drinking" and "low ethanol-drinking" mice was significantly changed $\left(\mathrm{F}(2,19)=3.83, p=0.04, \eta p^{2}=0.29\right.$; Figure 4D). Post hoc Newman-Keuls analysis revealed that the expression level of Tph2 in the raphe nuclei of mice that exhibited high levels of ethanol intake was significantly increased compared to "low ethanol-drinking" mice ( $p=0.037$; Figure 4D). Importantly, the raphe nuclei Tph $2 \mathrm{mRNA}$ levels in high or 
low ethanol-drinking mice did not differ compared to control mice $(p=0.93$ or $p=0.076$, respectively; Figure 4D).

No change in the level of Tph 2 mRNA was observed in the hippocampus of mice with high and low levels of ethanol consumption during the last week of ethanol exposure $\left(\mathrm{F}(2,19)=0.80, p=0.46, \eta \mathrm{p}^{2}=0.078\right.$; Figure $\left.4 \mathrm{D}\right)$.

There was a significant change in Tph2 expression in the prefrontal cortex of "high ethanol-drinking" and "low ethanol-drinking" mice during the last week of ethanol consumption $\left(\mathrm{F}(2,19)=4.96, p=0.019, \eta \mathrm{p}^{2}=0.34\right.$; Figure $\left.4 \mathrm{D}\right)$. Post hoc Newman-Keuls analysis revealed that the expression level of $T p h 2$ in the prefrontal cortex of mice that exhibited high levels of ethanol intake was significantly decreased compared to mice drinking water $(p=0.022)$ or animals that consumed low levels of ethanol $(p=0.049)$ (Figure 4D). Importantly, the prefrontal cortex Tph 2 mRNA levels in "low ethanol-drinking" mice did not differ compared to control mice ( $p=0.95$; Figure 4D).

Overall, the amount of Tph2 mRNA in the raphe nuclei of control animals was almost two orders of magnitude higher than the level of Tph2 mRNA in the hippocampus and prefrontal cortex. Division of mice into "high ethanol-drinking" and "low ethanol-drinking" animals showed that, in high ethanol drinkers, the Tph2 expression level was increased in the raphe nuclei and reduced in the prefrontal cortex compared to low ethanol drinkers.

\section{Discussion}

This study revealed that Tph2 deficiency in mice induced an increase in ethanol consumption in a two-bottle choice test. $T p h 2^{-/-}$mice that were given continuous access to water only consumed more of that liquid compared to wild-types. However, following ethanol exposure, water consumption decreased to the level of $\mathrm{Tph}^{+/+}$animals with access to water and ethanol. Independent of ethanol treatment, Tph2 deficiency led to the reduction in swimming, but facilitated climbing behavior in the FST, without changes in immobility time. 5-HT depletion in Tph $2^{-/-}$mice did not influence the development of an antidepressant phenotype (reflected by the reduction of immobility time and an increase in swimming) in the FST following 29 days of ethanol consumption. Evaluation of mRNA levels by qPCR in wild-type mice drinking water revealed, besides strong Tph2 expression in the raphe nuclei, very low levels of Tph2 transcripts in the 5-HT projection areas, hippocampus, and prefrontal cortex. Overall, chronic ethanol consumption in wildtype mice did not affect Tph2 expression in these brain regions. However, in mice drinking high levels of ethanol during the last week of ethanol exposure, a higher Tph2 expression in the raphe nuclei and lower level of Tph 2 mRNA in the prefrontal cortex were noted in comparison to "low ethanol-drinking" mice.

In our study, we employed a 29-day two-bottle choice procedure, in which animals had continuous access to water and increasing ethanol concentrations, a model often used by many research groups to evaluate the effect of genetic variations on drug response [64-66]. Importantly, animals that we tested consumed less ethanol compared to what is reported in the literature in the same paradigm (daily ethanol intake for a $10 \%$ ethanol solution: $3 \mathrm{~g} / \mathrm{kg} / \mathrm{d}$; present study vs. $8 \mathrm{~g} / \mathrm{kg} / \mathrm{d}$ or higher; [65-67]). Nevertheless, the protocol used in the present work allowed us to demonstrate the ethanol-induced antidepressant response in the FST in the wild-type mice, as evidenced by decreased immobility time and increased swimming. Our findings in the FST are in line with a previous study that demonstrated antidepressant properties of ethanol following a 28-day voluntary $10 \%$ ethanol drinking [74].

The finding of enhanced ethanol drinking in $\mathrm{Tph} 2^{-/-}$mice is in line with previous studies showing that mice expressing the hypofunctional $\mathrm{R} 439 \mathrm{H}$ allele for the Tph2 gene consumed more ethanol-sucrose solution, had increased preference for ethanol, and reduced sensitivity to ethanol compared to the wild-type animals [50]. However, another study found that the R439H Tph2 knock-in mice exhibited no change in ethanol intake relative to the control animals, but, only under aversive conditions, motivation for ethanol consumption increased [51]. While the methodological differences (e.g., the use of sucrose- 
fading procedure [50]; or the introduction of a 4-day withdrawal phase [51]) may account for the observed inconsistencies in studies of $\mathrm{R} 439 \mathrm{H}$ Tph 2 mutant mice, the variability in drinking-related outcomes between these animals and $T p h 2^{-/-}$mice is likely to be related to the extent of the brain 5-HT depletion. Indeed, $\mathrm{R} 439 \mathrm{H}$ mutation in Tph2 gene resulted in partial (60-80\%) reduction in 5-HT levels in the frontal cortex, amygdala, striatum, and hippocampus [46-49]. In contrast, complete inactivation of the Tph2 gene in mice used in the current study evoked severe ( $>98 \%$ ) 5-HT depletion in all the tested brain regions, including those analyzed in R439H Tph2 mice [56]. Hence, the brain area which drives 5-HT-dependent alcohol drinking remains unclear. Chemogenetic inhibition of specific 5-HT pathways originating from the raphe nuclei may be instrumental in identifying such brain areas.

In the FST, ethanol-naïve Tph $2^{-/-}$mice displayed a decrease in swimming, confirming previous data showing that swimming is a 5-HT-related parameter [75]. A reduction in swimming time in $T p h 2^{-/-}$mice may suggest that these animals developed a modest depression-like state. These results partially support our previous study, in which Tph2-/mice showed a reduced latency to immobility and increased immobility time in the FST, although, in this case, the swimming and climbing time were not assessed independently [60]. The other literature data regarding the behavior of Tph2 ${ }^{-/-}$mice in the FST are heterogeneous: either a reduced latency to immobility or a mild antidepressant phenotype were reported [57-59]. As previously discussed [60], the expression of depression-like behavior in Tph $2^{-/-}$mice in the FST may depend on specific protocols used to evaluate depressionlike behavior (e.g., FST session day), age of the animals, or genetic background on which the knockouts were created. In addition, the reduction in fat content or compensatory mechanisms resulting from a life-long depletion of 5-HT signaling in the brain in Tph $2^{-/-}$ mice may account for different outcomes in the FST (for review [63]).

Importantly, here we show for the first time that chronic ethanol consumption in 5-HTdepleted mice reduced immobility time and enhanced motor behavior, indicating that the 5-HT neurotransmission per se is not essential for the development of the antidepressant effect of ethanol. Additionally, it can be assumed that enhanced ethanol consumption in mice with low 5-HT function facilitated the antidepressant properties of ethanol and compensated for the negative state observed in drug-naive $T p h 2^{-/-}$mice. Interestingly, similar to $T p h 2^{-/-}$mice, in the Sardinian alcohol-preferring rat line, an animal model used to study alcohol dependence, an enhancement of ethanol drinking and reduction in the depression-like state were also accompanied by deficits in 5-HT function in the brain $[26,76]$. Thus, Tph $2^{-1-}$ mice may serve as a model for the study of ethanol dependence in the future. Importantly, the increased ethanol consumption observed in mice depleted in brain 5-HT corresponds well to the characteristics of a subset of alcoholics with early-onset type II alcoholism (Cloninger type-2-like) that has also been associated with 5-HT hypofunction (for review [7]). Many common typologies, such as comorbid psychopathology (i.e., depression), antisocial phenotype, or no reactivity to SSRIs $[7,58,62]$, have been found between Tph $2^{-1-}$ mice and type II alcoholics, despite differences in the origin of impaired 5-HT transmission (Tph2 deletion; present study vs. homozygosity for the long (L) allele for 5-HTT gene; [7]). Future studies on Tph $2^{-/-}$mice will be instrumental in discovering novel non-serotoninergic medications for the treatment of type II alcoholics.

Behavioral phenotype in Tph $2^{-/-}$mice, including enhanced ethanol consumption could be due to the adaptation mechanisms compensating for the continuous depletion in 5-HT, rather than the lack of 5-HT per se. Previously, we detected no marked differences in gene expression in the whole brain of $T p h 2^{-/-}$mice compared to controls using Affymetrix [56]. Importantly, another research group has found an upregulation of 5- $\mathrm{HT}_{1 \mathrm{~A}}$ and $5-\mathrm{HT}_{1 \mathrm{~B}}$ receptors in several brain regions, including the septum and frontal cortex of mice with constitutive inactivation of Tph2 [77]. To confirm the existence of compensatory changes within the 5-HT system in our Tph $2^{-/-}$mice, further functional and gene expression analyses of defined brain structures need to be performed. 
Importantly, aggression, sexual behavior, consumption of food, water, and addictive substances are associated with activation of the brain's reward system. The reinforcement of these behaviors seen in Tph2 $2^{-/}$mice ([60-62]; present study) may suggest an attenuated reward sensitivity [78] in response to the life-long 5-HT depletion. Indeed, constitutive inactivation of Tph2 induced a reduction in the hippocampal dopamine [77], the key signaling molecule of the reward system [78]. Certainly, for an appropriate interpretation of the current results suggesting the hypodopaminergic state in 5-HT-depleted mice, the analysis of other components of the dopamine system, e.g., the expression level of the $\mathrm{D}_{2}$ receptor, as well as dopamine release in other regions of the reward system, including the prefrontal cortex, nucleus accumbens, or amygdala, should be carried out.

Tph 2 mRNA and protein are produced in cell bodies of 5-HT neurons of the brainstem raphe nuclei. It is generally accepted that slow axonal transport is responsible for the TPH2 enzyme delivery to the terminal field for the local 5-HT synthesis [79]. However, axonal Tph 2 mRNA transport to the projection areas, such as the cortex, hippocampus, striatum, hypothalamus, and cerebellum, cannot be excluded [80,81]. In this study, we analyzed the Tph 2 mRNA level in the brainstem raphe nuclei containing 5-HT-synthesizing neurons, and the hippocampus and prefrontal cortex-areas rich in 5-HT terminals and two ethanol-responsive parts of the mesocorticolimbic dopamine circuitry [82,83]. Very low levels of Tph 2 transcripts were detectable in the hippocampus and prefrontal cortex in comparison to the raphe nuclei, confirming previous studies in rats [84].

In the present work, we found that $T p h 2^{+/+}$mice drinking ethanol exhibited no change in the Tph2 transcript level in the raphe nuclei, hippocampus, and prefrontal cortex in comparison to control water-drinking animals. However, when the Tph 2 expression was compared between mice that consumed high and low levels of ethanol, we observed that Tph2 expression in the raphe nuclei of "high ethanol-drinking" mice was $24 \%$ higher compared to "low ethanol-drinking" mice. Interestingly, at the same time, "high ethanoldrinking" animals displayed a reduced level of Tph2 transcript in the prefrontal cortex compared to "low ethanol-drinking" mice. Differences in Tph2 expression in the brainstem raphe nuclei and prefrontal cortex were observed only between mice that exhibited variability in the level of ethanol intake within the fourth week of ethanol exposure, but not those during the initial drug consumption. These findings may indicate that the differences in Tph 2 gene expression in the raphe nuclei and prefrontal cortex resulted from the chronic ethanol exposure rather than inter-individual traits, suggesting that modulation of the activity of TPH2 enzyme involved in 5-HT synthesis may represent a neuroplastic feedback mechanism during the development of ethanol-drinking behavior in mice. Since such a correlation was not observed in the hippocampus, it is unlikely that hippocampal Tph2 transcripts contribute to voluntary ethanol consumption in mice. Moreover, considering a very low Tph2 transcript level in the prefrontal cortex, it seems doubtful whether the observed decreases in Tph2 expression in this brain region in "high ethanol-drinking" mice have any relevance to the development of ethanol-drinking phenotype.

The effects of chronic voluntary ethanol consumption on neuroadaptations within the 5-HT neurotransmission, particularly in the raphe nuclei, have been studied to a limited extent. Consistent with our findings, a recent study has demonstrated no change in Tph 2 mRNA level in the raphe nuclei of mice after chronic (for 6 weeks) 10\% ethanol consumption [85]. Additionally, Popova et al. [85] have shown increases in the activity of the TPH2 enzyme and 5-HT turnover, and the transcript level (but not protein) of the 5- $\mathrm{HT}_{7}$ receptor in the midbrain raphe nuclei of animals after chronic ethanol intake. Importantly, no change in 5 - $\mathrm{HT}$ content and $5-\mathrm{HT}_{1 \mathrm{~A}}$ receptor gene expression has been reported in the midbrain, frontal cortex, hippocampus, hypothalamus, and amygdala of mice after chronic ethanol [85]. In contrast, another group that used a progressive ethanol exposure protocol (3-10\%, for 3 weeks), similar to the one we used in the current study, has found that chronic ethanol intake evoked an increase in $5-\mathrm{HT}_{1 \mathrm{~A}}$ autoreceptor sensitivity in the dorsal raphe nucleus of mice, suggesting a reduction in central 5-HT tone after chronic ethanol [67]. These discrepancies between studies could result from the fact that both 
analyses included mice, which, according to the observations in the present study, may have displayed inter-individual variations in the 5-HT response to chronic ethanol.

Previously, we have reported that a 50\% reduction in Tph 2 mRNA in the whole brain resulting from the absence of one copy of the Tph 2 gene in heterozygous Tph $2^{+/-}$mice has led to about a $13 \%$ decrease in 5-HT level in the whole brain [68]. Another study on heterozygous Tph 2 mutant mice revealed about a $22 \%$ reduction in 5-HT in the rostral raphe nuclei, but not in the hippocampus, frontal cortex, or thalamus [77]. Importantly, such a decrease in the central 5-HT content did not affect the depressive, anxiety, and aggressive behavior [60,68], and ethanol-drinking behavior has not been evaluated in these mice. Other studies have shown that two mouse strains exhibiting low preference for ethanol, BALB/cJ and DBA/2A [53,54], harbored the C1473G (P447R) single-nucleotide polymorphism within the Tph2 gene [52]. Besides this mutation, BALB/cJ mice displayed a decrease in the Tph 2 mRNA level (by ca. 20\%) and the number of TPH2-immunoreactive neurons (by 28\%) in the dorsal raphe nucleus, and, consequently, a reduction (by 15\%) in 5-HT content in the midbrain and cortex compared to high-ethanol-preferring C57B/6J mice $[53,55]$ that were homozygous for the high-activity $1473 \mathrm{C}$ allele for Tph2 [52]. Based on these findings, lower Tph 2 transcript levels in the raphe nuclei observed in the present study in "low ethanol-drinking" mice may potentially coincide with decreased central 5-HT levels and represent an ethanol-resilient phenotype. Further studies are necessary to verify whether reduction in Tph2 gene expression in mice consuming low levels of ethanol has any impact on TPH2 activity and/or 5-HT level.

Rats consuming high levels of ethanol exhibited blunted hypothalamic-pituitaryadrenocortical axis responses compared to low-ethanol-consuming animals [86]. On the other hand, another investigation has shown that the reduction in the glucocorticoid level induced by adrenalectomy enhanced Tph 2 gene expression in the mouse raphe nuclei [87], indicating that Tph 2 gene expression is sensitive to glucocorticoid signaling. Whether the high and low Tph 2 gene expression observed in mice in the present study is related to the fluctuation in the glucocorticoid level in the brain and plasma needs to be further assessed.

In summary, we propose that the life-long 5-HT depletion in the brain predisposes to increased ethanol consumption. However, it is not clear whether the effect is due to the lack of 5-HT per se or, rather, a compensatory response to the long-term deficiency in 5-HT synthesis. Moreover, we conclude that the absence of central 5-HT does not interfere with the antidepressant properties of ethanol. Our results indicate that regulation of Tph2 gene expression in the raphe nuclei, and possibly prefrontal cortex, may be specifically involved in the development of ethanol-drinking behavior in mice.

Limitations of the study include the selection criteria of mice with high and low ethanol intake levels, which were due to the small group size $(n=17)$. Nevertheless, such conditions for selecting the "ethanol drinking phenotype" were sufficient to detect differences in the Tph2 transcript levels, suggesting specificity of the observed changes. Another limitation is that we did not measure the 5-HT level within these animals.

Further more detailed molecular analysis of a larger group size and rodent lines selectively bred for high and low ethanol consumption is urgently needed to confirm the present findings regarding the importance of Tph2 expression in development of ethanol drinking behavior. Modulation of TPH2 expression and/or activity by appropriate tools in the future will verify whether such a strategy will induce resilience to ethanol.

Author Contributions: Conceptualization, M.Z., M.B. and N.A.; Methodology, M.Z., V.M. and N.A.; Investigation-generation of Tph2 $2^{-/-}$mice, V.M.; Investigation-behavioral and molecular experiments, M.Z.; Visualization—data presentation, M.Z.; Formal Analysis, M.Z.; Writing-Original Draft Preparation, M.Z.; Writing-Review, V.M., M.B. and N.A.; Writing—Editing, M.Z. All authors have read and agreed to the published version of the manuscript.

Funding: This research was supported by the EU H2020 MSCA ITN projects "Serotonin and Beyond" (N 953327) to M.B. and N.A. M.Z. was supported by Ministry of Science and Higher Education (Warszawa, Poland), grant no. 632/MOB/2011/0 and by statutory funds of Maj Institute of Pharma- 
cology, Polish Academy of Sciences (Kraków, Poland). V.M. was supported by a fellowship from the German Academic Exchange Service (DAAD, A07/99669).

Institutional Review Board Statement: The study was conducted according to the guidelines of the Declaration of Helsinki, and approved by the local animal welfare and ethical review body (Landesamt für Gesundheit und Soziales Berlin (LaGeSo), G 0343/09, date of approval: 24 March 2010).

Informed Consent Statement: Not applicable.

Data Availability Statement: All data supporting the conclusions of this manuscript are provided in the text and figures.

Acknowledgments: The authors acknowledge Agnieszka Pac, Chair of Epidemiology and Preventive Medicine, Jagiellonian University Medical College (Kraków, Poland) for her expert statistical advice.

Conflicts of Interest: The authors declare no conflict of interest.

\section{References}

1. Crowley, P. Long-term drug treatment of patients with alcohol dependence. Aust. Prescr. 2015, 38, 41. [CrossRef] [PubMed]

2. Morley, K.; Perry, C.; Watt, J.; Hurzeler, T.; Leggio, L.; Lawrence, A.; Haber, P. New approved and emerging pharmacological approaches to alcohol use disorder: A review of clinical studies. Expert Opin. Pharmacother. 2021, 22, 1291-1303. [CrossRef] [PubMed]

3. Shield, K.D.; Parry, C.; Rehm, J. Chronic Diseases and Conditions Related to Alcohol Use. Alcohol Res. Curr. Rev. $2014,35,155$.

4. Polimanti, R.; Peterson, R.; Ong, J.; MacGregor, S.; Edwards, A.; Clarke, T.; Frank, J.; Gerring, Z.; Gillespie, N.; Lind, P.; et al. Evidence of causal effect of major depression on alcohol dependence: Findings from the psychiatric genomics consortium. Psychol. Med. 2019, 49, 1218-1226. [CrossRef] [PubMed]

5. Boden, J.; Fergusson, D. Alcohol and depression. Addiction 2011, 106, 906-914. [CrossRef]

6. Ruhé, H.G.; Mason, N.S.; Schene, A.H. Mood is indirectly related to serotonin, norepinephrine and dopamine levels in humans: A meta-analysis of monoamine depletion studies. Mol. Psychiatry 2007, 12, 331-359. [CrossRef] [PubMed]

7. Marcinkiewcz, C. Serotonergic Systems in the Pathophysiology of Ethanol Dependence: Relevance to Clinical Alcoholism. ACS Chem. Neurosci. 2015, 6, 1026-1039. [CrossRef]

8. Buydens-Branchey, L.; Branchey, M.; Noumair, D.; Lieber, C. Age of alcoholism onset. II. Relationship to susceptibility to serotonin precursor availability. Arch. Gen. Psychiatry 1989, 46, 231-236. [CrossRef] [PubMed]

9. Patkar, A.A.; Gopalakrishnan, R.; Naik, P.C.; Murray, H.W.; Vergare, M.J.; Marsden, C.A. Changes in plasma noradrenaline and serotonin levels and craving during alcohol withdrawal. Alcohol Alcohol. 2003, 38, 224-231. [CrossRef] [PubMed]

10. Ballenger, J.C.; Goodwin, F.K.; Major, L.F.; Brown, G.L. Alcohol and Central Serotonin Metabolism in Man. Arch. Gen. Psychiatry 1979, 36, 224-227. [CrossRef] [PubMed]

11. Rosenthal, N.E.; Davenport, Y.; Cowdry, R.W.; Webster, M.H.; Goodwin, F.K. Monoamine metabolites in cerebrospinal fluid of depressive subgroups. Psychiatry Res. 1980, 2, 113-119. [CrossRef]

12. Dougherty, D.M.; Marsh, D.M.; Mathias, C.W.; Dawes, M.A.; Bradley, D.M.; Morgan, C.J.; Badawy, A.A.B. The effects of alcohol on laboratory-measured impulsivity after L-Tryptophan depletion or loading. Psychopharmacology 2007, 193, 137-150. [CrossRef] [PubMed]

13. Petrakis, I.L.; Buonopane, A.; O’Malley, S.; Cermik, O.; Trevisan, L.; Boutros, N.N.; Limoncelli, D.; Krystal, J.H. The effect of tryptophan depletion on alcohol self-administration in non-treatment-seeking alcoholic individuals. Alcohol. Clin. Exp. Res. 2002, 26, 969-975. [CrossRef] [PubMed]

14. Petrakis, I.; Trevisan, L.; Boutros, N.; Limoncelli, D.; Cooney, N.; Krysta, J. Effect of tryptophan depletion on alcohol cue-induced craving in abstinent alcoholic patients. Alcohol Clin. Exp. Res. 2001, 25, 1151-1155. [CrossRef]

15. Kranzler, H.R.; Armeli, S.; Tennen, H.; Covault, J.; Feinn, R.; Arias, A.J.; Pettinati, H.; Oncken, C. A double-blind, randomized trial of sertraline for alcohol dependence: Moderation by age and 5-hydroxytryptamine transporter-linked promoter region genotype. J. Clin. Psychopharmacol. 2011, 31, 22-30. [CrossRef] [PubMed]

16. Cornelius, J.; Salloum, I.; Cornelius, M.; Perel, J.; Ehler, J.; Jarrett, P.; Levin, R.; Black, A.; Mann, J. Preliminary report: Double-blind, placebo-controlled study of fluoxetine in depressed alcoholics. Psychopharmacol. Bull. 1995, 31, 297-303. [PubMed]

17. Agabio, R.; Trogu, E.; Pani, P.P. Antidepressants for the treatment of people with co-occurring depression and alcohol dependence. Cochrane Database Syst. Rev. 2018, 4. [CrossRef]

18. Gorelick, D.A. Serotonin uptake blockers and the treatment of alcoholism. Recent Dev. Alcohol. 1989, 7, $267-281$.

19. Babor, T.; Hofmann, M.; DelBoca, F.; Hesselbrock, V.; Meyer, R.; Dolinsky, Z.; Rounsaville, B. Types of alcoholics, I. Evidence for an empirically derived typology based on indicators of vulnerability and severity. Arch. Gen. Psychiatry 1992, 49, 599-608. [CrossRef] [PubMed]

20. Pettinati, H.; Volpicelli, J.; Kranzler, H.; Luck, G.; Rukstalis, M.; Cnaan, A. Sertraline treatment for alcohol dependence: Interactive effects of medication and alcoholic subtype. Alcohol. Clin. Exp. Res. 2000, 24, 1041-1049. [CrossRef] [PubMed] 
21. Dundon, W.; Lynch, K.; Pettinati, H.; Lipkin, C. Treatment outcomes in type A and B alcohol dependence 6 months after serotonergic pharmacotherapy. Alcohol. Clin. Exp. Res. 2004, 28, 1065-1073. [CrossRef] [PubMed]

22. Kranzler, H.; Burleson, J.; Brown, J.; Babor, T. Fluoxetine treatment seems to reduce the beneficial effects of cognitive-behavioral therapy in type B alcoholics. Alcohol. Clin. Exp. Res. 1996, 20, 1534-1541. [CrossRef] [PubMed]

23. Murphy, J.; McBride, W.; Lumeng, L.; Li, T. Regional brain levels of monoamines in alcohol-preferring and -nonpreferring lines of rats. Pharmacol. Biochem. Behav. 1982, 16, 145-149. [CrossRef]

24. Ahtee, L.; Eriksson, K. 5-Hydroxytryptamine and 5-hydroxyindolylacetic acid content in brain of rat strains selected for their alcohol intake. Physiol. Behav. 1972, 8, 123-126. [CrossRef]

25. Aulakh, C.; Tolliver, T.; Wozniak, K.; Hill, J.; Murphy, D. Functional and biochemical evidence for altered serotonergic function in the fawn-hooded rat strain. Pharmacol. Biochem. Behav. 1994, 49, 615-620. [CrossRef]

26. Casu, M.; Pisu, C.; Lobina, C.; Pani, L. Immunocytochemical study of the forebrain serotonergic innervation in Sardinian alcohol-preferring rats. Psychopharmacology 2004, 172, 341-351. [CrossRef] [PubMed]

27. Smith, A.; Weiss, F. Ethanol exposure differentially alters central monoamine neurotransmission in alcohol-preferring versus -nonpreferring rats. J. Pharm. Exp. Ther. 1999, 288, 1223-1228.

28. Jessa, M.; Krzaścik, P.; Kostowski, W. Neonatal treatment with 5,7-dihydroxytryptamine induces decrease in alcohol drinking in adult animals. Pol. J. Pharmacol. 2001, 53, 109-116. [PubMed]

29. Myers, R.; Melchior, C. Alcohol drinking in the rat after destruction of serotonergic and catecholaminergic neurons in the brain. Res. Commun. Chem. Pathol. Pharmacol. 1975, 10, 363-378. [PubMed]

30. Vasudeva, R.K.; Hobby, A.R.; Kirby, L.G. Ethanol consumption in the Sprague-Dawley rat increases sensitivity of the dorsal raphe nucleus to 5,7-dihydroxytryptamine. Behav. Brain Res. 2015, 295, 35-44. [CrossRef] [PubMed]

31. Adell, A.; Myers, R. Selective destruction of midbrain raphe nuclei by 5,7-DHT: Is brain 5-HT involved in alcohol drinking in Sprague-Dawley rats? Brain Res. 1995, 693, 70-79. [CrossRef]

32. Wang, J.; Shum, A.; Lin, T.; Wang, Y. Central serotonergic lesions increase voluntary alcohol consumption in Sprague Dawley rats: Moderation by long-term ethanol administration. Alcohol. Clin. Exp. Res. 1996, 20, 1252-1259. [CrossRef] [PubMed]

33. Baumgarten, H.; Lachenmayer, L. 5,7-dihydroxytryptamine: Improvement in chemical lesioning of indoleamine neurons in the mammalian brain. Z. Zellforsch. Mikrosk. Anat. 1972, 135, 399-414. [CrossRef] [PubMed]

34. Neal, K.B.; Parry, L.J.; Bornstein, J.C. Strain-specific genetics, anatomy and function of enteric neural serotonergic pathways in inbred mice. J. Physiol. 2009, 587, 567-586. [CrossRef] [PubMed]

35. Walther, D.J.; Peter, J.U.; Bashammakh, S.; Hörtnagl, H.; Voits, M.; Fink, H.; Bader, M. Synthesis of serotonin by a second tryptophan hydroxylase isoform. Science 2003, 299, 76. [CrossRef] [PubMed]

36. Gutknecht, L.; Kriegebaum, C.; Waider, J.; Schmitt, A.; Lesch, K. Spatio-temporal expression of tryptophan hydroxylase isoforms in murine and human brain: Convergent data from Tph2 knockout mice. Eur. Neuropsychopharmacol. 2009, 19, 266-282. [CrossRef] [PubMed]

37. Bach, H.; Arango, V.; Kassir, S.A.; Tsaava, T.; Dwork, A.J.; Mann, J.J.; Underwood, M.D. Alcoholics have more tryptophan hydroxylase 2 mRNA and protein in the dorsal and median raphe nuclei. Alcohol. Clin. Exp. Res. 2014, 38, 1894-1901. [CrossRef]

38. Underwood, M.; Mann, J.; Arango, V. Morphometry of dorsal raphe nucleus serotonergic neurons in alcoholism. Alcohol. Clin. Exp. Res. 2007, 31, 837-845. [CrossRef] [PubMed]

39. Bonkale, W.; Turecki, G.; Austin, M. Increased tryptophan hydroxylase immunoreactivity in the dorsal raphe nucleus of alcohol-dependent, depressed suicide subjects is restricted to the dorsal subnucleus. Synapse 2006, 60, 81-85. [CrossRef] [PubMed]

40. Zhang, X.; Gainetdinov, R.; Beaulieu, J.; Sotnikova, T.; Burch, L.; Williams, R.; Schwartz, D.; Krishnan, K.; Caron, M. Loss-offunction mutation in tryptophan hydroxylase-2 identified in unipolar major depression. Neuron 2005, 45, 11-16. [CrossRef] [PubMed]

41. Matthes, S.; Mosienko, V.; Bashammakh, S.; Alenina, N.; Bader, M. Tryptophan Hydroxylase as Novel Target for the Treatment of Depressive Disorders. Pharmacology 2010, 85, 95-109. [CrossRef] [PubMed]

42. Agrawal, A.; Lynskey, M.; Todorov, A.; Schrage, A.; Littlefield, A.; Grant, J.; Zhu, Q.; Nelson, E.; Madden, P.; Bucholz, K.; et al. A candidate gene association study of alcohol consumption in young women. Alcohol. Clin. Exp. Res. 2011, 35, 550-558. [CrossRef] [PubMed]

43. Plemenitaš, A.; Kores Plesničar, B.; Kastelic, M.; Porcelli, S.; Serretti, A.; Dolžan, V. Genetic variability in tryptophan hydroxylase 2 gene in alcohol dependence and alcohol-related psychopathological symptoms. Neurosci. Lett. 2015, 604, 86-90. [CrossRef] [PubMed]

44. Zill, P.; Preuss, U.; Koller, G.; Bondy, B.; Soyka, M. SNP- and haplotype analysis of the tryptophan hydroxylase 2 gene in alcohol-dependent patients and alcohol-related suicide. Neuropsychopharmacology 2007, 32, 1687-1694. [CrossRef] [PubMed]

45. Gacek, P.; Conner, T.; Tennen, H.; Kranzler, H.; Covault, J. Tryptophan hydroxylase 2 gene and alcohol use among college students. Addict. Biol. 2008, 13, 440-448. [CrossRef] [PubMed]

46. Jacobsen, J.; Siesser, W.; Sachs, B.; Peterson, S.; Cools, M.; Setola, V.; Folgering, J.; Flik, G.; Caron, M. Deficient serotonin neurotransmission and depression-like serotonin biomarker alterations in tryptophan hydroxylase 2 (Tph2) loss-of-function mice. Mol. Psychiatry 2012, 17, 694-704. [CrossRef] [PubMed] 
47. Sachs, B.D.; Rodriguiz, R.M.; Siesser, W.B.; Kenan, A.; Royer, E.L.; Jacobsen, J.P.R.; Wetsel, W.C.; Caron, M.G. The effects of brain serotonin deficiency on behavioural disinhibition and anxiety-like behaviour following mild early life stress. Int. J. Neuropsychopharmacol. 2013, 16, 2081-2094. [CrossRef]

48. Beaulieu, J.M.; Zhang, X.; Rodriguiz, R.M.; Sotnikova, T.D.; Cools, M.J.; Wetsel, W.C.; Gainetdinov, R.R.; Caron, M.G. Role of GSK3 beta in behavioral abnormalities induced by serotonin deficiency. Proc. Natl. Acad. Sci. USA 2008, 105, 1333-1338. [CrossRef] [PubMed]

49. Lavoie, J.; Illiano, P.; Sotnikova, T.D.; Gainetdinov, R.R.; Beaulieu, J.M.; Hébert, M. The electroretinogram as a biomarker of central dopamine and serotonin: Potential relevance to psychiatric disorders. Biol. Psychiatry 2014, 75, 479-486. [CrossRef] [PubMed]

50. Sachs, B.; Salahi, A.; Caron, M. Congenital brain serotonin deficiency leads to reduced ethanol sensitivity and increased ethanol consumption in mice. Neuropharmacology 2014, 77, 177-184. [CrossRef] [PubMed]

51. Lemay, F.; Doré, F.; Beaulieu, J. Increased ethanol consumption despite taste aversion in mice with a human tryptophan hydroxylase 2 loss of function mutation. Neurosci. Lett. 2015, 609, 194-197. [CrossRef] [PubMed]

52. Zhang, X.; Beaulieu, J.M.; Sotnikova, T.D.; Gainetdinov, R.R.; Caron, M.G. Tryptophan hydroxylase-2 controls brain synthesis. Science 2004, 305, 217. [CrossRef]

53. Elmer, G.; Meisch, R.; George, F. Mouse strain differences in operant self-administration of ethanol. Behav. Genet. 1987, 17, 439-451. [CrossRef] [PubMed]

54. He, X.; Nebert, D.; Vasiliou, V.; Zhu, H.; Shertzer, H. Genetic differences in alcohol drinking preference between inbred strains of mice. Pharmacogenetics 1997, 7, 223-233. [CrossRef]

55. Bach, H.; Arango, V.; Huang, Y.; Leong, S.; Mann, J.; Underwood, M. Neuronal tryptophan hydroxylase expression in BALB/cJ and C57Bl/6J mice. J. Neurochem. 2011, 118, 1067-1074. [CrossRef] [PubMed]

56. Alenina, N.; Kikic, D.; Todiras, M.; Mosienko, V.; Qadri, F.; Plehm, R.; Boyé, P.; Vilianovitch, L.; Sohr, R.; Tenner, K.; et al. Growth retardation and altered autonomic control in mice lacking brain serotonin. Proc. Natl. Acad. Sci. USA 2009, 106, 10332-10337. [CrossRef]

57. Savelieva, K.V.; Zhao, S.; Pogorelov, V.M.; Rajan, I.; Yang, Q.; Cullinan, E.; Lanthorn, T.H. Genetic disruption of both tryptophan hydroxylase genes dramatically reduces serotonin and affects behavior in models sensitive to antidepressants. PLoS ONE 2008, 3, e3301. [CrossRef] [PubMed]

58. Angoa-Pérez, M.; Kane, M.J.; Briggs, D.I.; Herrera-Mundo, N.; Sykes, C.E.; Francescutti, D.M.; Kuhn, D.M. Mice genetically depleted of brain serotonin do not display a depression-like behavioral phenotype. ACS Chem. Neurosci. 2014, 5, 908-919. [CrossRef] [PubMed]

59. Gutknecht, L.; Popp, S.; Waider, J.; Sommerlandt, F.M.J.; Göppner, C.; Post, A.; Reif, A.; Van Den Hove, D.; Strekalova, T.; Schmitt, A.; et al. Interaction of brain 5-HT synthesis deficiency, chronic stress and sex differentially impact emotional behavior in Tph2 knockout mice. Psychopharmacology 2015, 232, 2429-2441. [CrossRef] [PubMed]

60. Mosienko, V.; Bert, B.; Beis, D.; Matthes, S.; Fink, H.; Bader, M.; Alenina, N. Exaggerated aggression and decreased anxiety in mice deficient in brain serotonin. Transl. Psychiatry 2012, 2, e122. [CrossRef]

61. van Lingen, M.; Sidorova, M.; Alenina, N.; Klempin, F. Lack of Brain Serotonin Affects Feeding and Differentiation of Newborn Cells in the Adult Hypothalamus. Front. Cell Dev. Biol. 2019, 7, 65. [CrossRef]

62. Beis, D.; Holzwarth, K.; Flinders, M.; Bader, M.; Wöhr, M.; Alenina, N. Brain serotonin deficiency leads to social communication deficits in mice. Biol. Lett. 2015, 11, 20150057. [CrossRef] [PubMed]

63. Mosienko, V.; Beis, D.; Pasqualetti, M.; Waider, J.; Matthes, S.; Qadri, F.; Bader, M.; Alenina, N. Life without brain serotonin: Reevaluation of serotonin function with mice deficient in brain serotonin synthesis. Behav. Brain Res. 2015, 277, 78-88. [CrossRef] [PubMed]

64. Fructuoso, M.; Gu, Y.C.; Kassis, N.; de Lagran, M.M.; Dierssen, M.; Janel, N. Ethanol-Induced Changes in Brain of Transgenic Mice Overexpressing DYRK1A. Mol. Neurobiol. 2020, 57, 3195-3205. [CrossRef] [PubMed]

65. Yoneyama, N.; Crabbe, J.C.; Ford, M.M.; Murillo, A.; Finn, D.A. Voluntary ethanol consumption in 22 inbred mouse strains Alcohol 2008, 42, 149-160. [CrossRef] [PubMed]

66. Lim, J.P.; Zou, M.E.; Janak, P.H.; Messing, R.O. Responses to ethanol in C57BL/6 versus C57BL/ $6 \times 129$ hybrid mice. Brain Behav. 2012, 2, 22-31. [CrossRef]

67. Kelaï, S.; Renoir, T.; Chouchana, L.; Saurini, F.; Hanoun, N.; Hamon, M.; Lanfumey, L. Chronic voluntary ethanol intake hypersensitizes 5-HT(1A) autoreceptors in C57BL/6J mice. J. Neurochem. 2008, 107, 1660-1670. [CrossRef]

68. Mosienko, V.; Matthes, S.; Hirth, N.; Beis, D.; Flinders, M.; Bader, M.; Hansson, A.C.; Alenina, N. Adaptive changes in serotonin metabolism preserve normal behavior in mice with reduced TPH2 activity. Neuropharmacology 2014, 85, 73-80. [CrossRef] [PubMed]

69. Solich, J.; Pałach, P.; Budziszewska, B.; Dziedzicka-Wasylewska, M. Effect of two behavioral tests on corticosterone level in plasma of mice lacking the noradrenaline transporter. Pharm. Rep. 2008, 60, 1008-1013. [CrossRef]

70. Costa, A.P.R.; Vieira, C.; Bohner, L.O.; Silva, C.F.; da Silva Santos, E.C.; De Lima, T.C.M.; Lino-de-Oliveira, C. A proposal for refining the forced swim test in Swiss mice. Prog. Neuro-Psychopharmacol. Biol. Psychiatry 2013, 45, 150-155. [CrossRef] [PubMed]

71. McGuier, N.S.; Griffin, W.C.; Gass, J.T.; Padula, A.E.; Chesler, E.J.; Mulholland, P.J. Kv7 channels in the nucleus accumbens are altered by chronic drinking and are targets for reducing alcohol consumption. Addict. Biol. 2016, 21, 1097-1112. [CrossRef] [PubMed] 
72. Paxinos, G.; Franklin, K.B.J. The Mouse Brain in Stereotaxic Coordinates, 2nd ed.; Academic Press: San Diego, CA, USA, 2001.

73. Livak, K.J.; Schmittgen, T.D. Analysis of relative gene expression data using real-time quantitative PCR and the 2(-Delta Delta C(T)) Method. Methods 2001, 25, 402-408. [CrossRef] [PubMed]

74. Jiang, B.; Yang, W.; Xiu, Z.; Zhang, L.; Ren, X.; Wang, L.; Chen, L.; Asakawa, T. An in vivo explorative study to observe the protective effects of Puerariae flos extract on chronic ethanol exposure and withdrawal male mice. Biomed. Pharmacother. 2021, 137. [CrossRef]

75. Slattery, D.A.; Desrayaud, S.; Cryan, J.F. GABAB receptor antagonist-mediated antidepressant-like behavior is serotonindependent. J. Pharmacol. Exp. Ther. 2005, 312, 290-296. [CrossRef] [PubMed]

76. Ciccocioppo, R.; Panocka, I.; Froldi, R.; Colombo, G.; Gessa, G.; Massi, M. Antidepressant-like effect of ethanol revealed in the forced swimming test in Sardinian alcohol-preferring rats. Psychopharmacology 1999, 144, 151-157. [CrossRef] [PubMed]

77. Gutknecht, L.; Araragi, N.; Merker, S.; Waider, J.; Sommerlandt, F.; Mlinar, B.; Baccini, G.; Mayer, U.; Proft, F.; Hamon, M.; et al. Impacts of brain serotonin deficiency following Tph2 inactivation on development and raphe neuron serotonergic specification. PLoS ONE 2012, 7, e43157. [CrossRef] [PubMed]

78. Volkow, N.D.; Wang, G.-J.; Fowler, J.S.; Tomasi, D.; Telang, F.; Baler, R. Addiction: Decreased reward sensitivity and increased expectation sensitivity conspire to overwhelm the brain's control circuit. Bioessays. 2010, 32, 748-788. [CrossRef]

79. Roy, S. Finding order in slow axonal transport. Curr. Opin. Neurobiol. 2020, 63, 87-94. [CrossRef]

80. Sahoo, P.K.; Smith, D.S.; Perrone-Bizzozero, N.; Twiss, J.L. Axonal mRNA transport and translation at a glance. J. Cell Sci. 2018, 131, jcs196808. [CrossRef]

81. Dalla Costa, I.; Buchanan, C.N.; Zdradzinski, M.D.; Sahoo, P.K.; Smith, T.P.; Thames, E.; Kar, A.N.; Twiss, J.L. The functional organization of axonal mRNA transport and translation. Nat. Rev. Neurosci. 2020, 22, 77-91. [CrossRef] [PubMed]

82. Belmer, A.; Patkar, O.L.; Pitman, K.M.; Bartlett, S.E. Serotonergic Neuroplasticity in Alcohol Addiction. Brain Plast. 2016, 1 , 177-206. [CrossRef]

83. Vilpoux, C.; Warnault, V.; Pierrefiche, O.; Daoust, M.; Naassila, M. Ethanol-sensitive brain regions in rat and mouse: A cartographic review, using immediate early gene expression. Alcohol. Clin. Exp. Res. 2009, 33, 945-969. [CrossRef] [PubMed]

84. Carkaci-Salli, N.; Salli, U.; Kuntz-Melcavage, K.L.; Pennock, M.M.; Ozgen, H.; Tekin, I.; Freeman, W.M.; Vrana, K.E. TPH2 in the ventral tegmental area of the male rat brain. Brain Res. Bull. 2011, 84, 376-380. [CrossRef]

85. Popova, N.; Ilchibaeva, T.; Antonov, E.; Pershina, A.; Bazovkina, D.; Naumenko, V. On the interaction between BDNF and serotonin systems: The effects of long-term ethanol consumption in mice. Alcohol 2020, 87, 1-15. [CrossRef]

86. Richardson, H.; Lee, S.; O'Dell, L.; Koob, G.; Rivier, C. Alcohol self-administration acutely stimulates the hypothalamic-pituitaryadrenal axis, but alcohol dependence leads to a dampened neuroendocrine state. Eur. J. Neurosci. 2008, 28, 1641-1653. [CrossRef]

87. Heydendael, W.; Jacobson, L. Glucocorticoid status affects antidepressant regulation of locus coeruleus tyrosine hydroxylase and dorsal raphé tryptophan hydroxylase gene expression. Brain Res. 2009, 1288, 69-78. [CrossRef] 